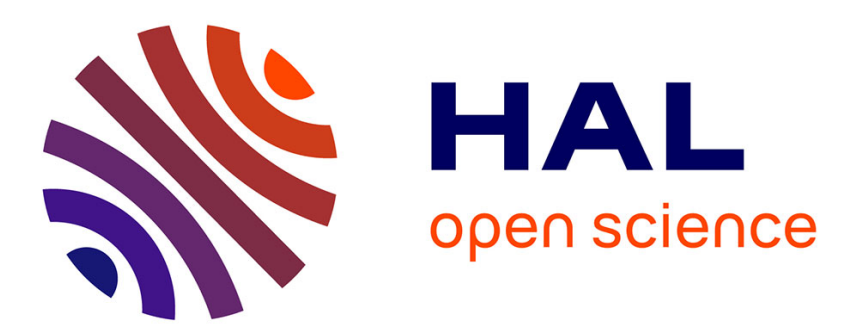

\title{
Does diversity of bank board members affect performance and risk? Evidence from an emerging market \\ Bowo Setiyono, Amine Tarazi
}

\section{- To cite this version:}

Bowo Setiyono, Amine Tarazi. Does diversity of bank board members affect performance and risk? Evidence from an emerging market. 2014. hal-01070988

\section{HAL Id: hal-01070988 \\ https: / hal-unilim.archives-ouvertes.fr/hal-01070988}

Preprint submitted on 2 Oct 2014

HAL is a multi-disciplinary open access archive for the deposit and dissemination of scientific research documents, whether they are published or not. The documents may come from teaching and research institutions in France or abroad, or from public or private research centers.
L'archive ouverte pluridisciplinaire HAL, est destinée au dépôt et à la diffusion de documents scientifiques de niveau recherche, publiés ou non, émanant des établissements d'enseignement et de recherche français ou étrangers, des laboratoires publics ou privés. 


\title{
Does diversity of bank board members affect performance and risk? Evidence from an emerging market
}

\author{
Bowo Setiyono $^{\mathrm{a} 1}$ and Amine Tarazi ${ }^{\mathrm{a}}$ \\ Université de Limoges, LAPE, 5 rue Félix Eboué, 87031 Limoges Cedex, France \\ This draft: September 4, 2014 \\ Please do not quote without the permission of the authors
}

\begin{abstract}
This study investigates the influence of background diversity of bank board members on performance and risk. Using data from Indonesian banks from 2001 to 2011 covering 4200 individual year observations and 21 ethnic groups, we estimate the degree of diversity by considering various aspects (gender, citizenship, age, experience, tenure, ethnicity, nationality, education level and type) and find significant impacts on bank performance. On the whole, diversity is in general positively associated with performance except when it relates to ethnicity. It not only reduces performance per se but also increases risk. Female presence and professional diversity reduce risk but nationality and ethnicity diversities are associated with higher risk. Education diversity generally leads to higher income volatility and leverage risk. Our results are generally robust to various alternative performance measures, including risk adjusted returns, and estimation methods.
\end{abstract}

JEL Classification: G21, G30, G34, J15, M14

Keywords: Bank Board, Performance, Risk, Diversity, Ethnicity, Emerging Market

\footnotetext{
${ }^{1}$ Corresponding author. Tel: + 33555149251

E-mail address : bowo.setiyono@etu.unilim.fr (B. Setiyono)
} 


\section{Introduction}

The financial crisis triggered in 2008 has called for further investigation on existing governance practices and board effectiveness in the banking industry. The poor performance of many banks has often been related to poor governance practices and the failure of board directors to perform in the best interest of stakeholders (Aebi et al., 2012; Beltratti and Stulz, 2012; Berger et al., 2012; Erkens et al., 2012). Other papers have questioned whether board structure actually matters for firm performance (e.g., Adams and Ferreira, 2007, 2009; Adams and Mehran, 2012; Anderson et al., 2011; Ferreira, 2010; Masulis et al., 2012; Pathan and Faff, 2013). In this work, we look into various characteristics of board members such as gender, citizenship, age, experience, tenure, ethnicity, education level and type to investigate the impact of background diversity of board members on bank profitability and risk.

It is widely accepted that banks' performance is closely related to various factors such as regulatory scrutiny, the degree of financial development and the existence of public safety nets such as deposit insurance systems. It is well understood that the banking industry is characterized by higher opacity and more complex agency conflicts than other industries (Levine, 2004; Morgan, 2002). Also, because of deregulation and cross border expansion in most countries, banks have to deal with a more diverse environment to such an extent that it is virtually imperative for them to consider a more diverse board. As such, board structure and its diversity can be crucial and significantly related to performance (Anderson et al., 2011; Ferreira, 2010). Furthermore, board structure is an important governance mechanism particularly in developing and emerging countries where other control mechanisms are commonly weaker (Claessens and Yurtoglu, 2013). Hence, when directors are regarded as important resources to the firm, various dimensions regarding their background and skills clearly become very important (Ferreira, 2010).

Generally, board diversity refers to a situation in which members have different social, cultural and professional backgrounds ${ }^{1}$. The main purpose of diversity is to enhance the

\footnotetext{
${ }^{1}$ Cox (2001) define diversity as the variation of social and cultural identities among people existing together in a defined employment or market setting, social and cultural identity refers to the personal affiliation with groups that research has shown to have significant influence on peoples' major life experiences. These affiliations include gender, race, national origin, religion, age cohort and work specialization, among others. The strains of literature typically distinguish heterogeneity or diversity into two types. First, the observable, the so-called demographic, heterogeneity, that can be described by gender, age, race, or ethnicity diversities. Second, the non-observables (cognitive) diversity includes education, values, perception and other personality characteristics (Milliken and Martins, 1996; Watson et al., 1998; Kilduff, et al., 2000; Timmerman, 2000). However, Erhardt (2003) suggest that most empirical literature on the diversity and firm
} 
ability of firms to tap into diverse markets and to increase market share within a global economy (Cox, 2001). A more heterogeneous board offers benefits from diverse members' skills and experiences which serve as complementary sources to access resources and connections (Davies et al., 2014; Ferreira, 2010).

However, from another perspective, diversity can be regarded as endogenous to the firm characteristics and a way out when boards deal with agency problems. Increasing the level of heterogeneity, for instance, does not necessarily bring in more benefits because of a failure to harmonize different backgrounds and mitigate potential conflicts among board members that could ultimately lead to a negative net outcome (e.g., Adams and Ferreira, 2009; Baranchuk and Dybvig, 2009). Also, board heterogeneity might only be regarded as an effort to comply with certain regulations ${ }^{2}$, or to demonstrate an absence of discrimination and therefore its impact on organizational performance is unclear (Erhardt et al., 2003). Hence, we investigate whether board members' diversity actually affects banks' performance and risk-taking. We also question whether a specific type of diversity (gender, citizenship, age, experience, tenure, ethnicity, nationality, education level and type) matters more in explaining cross sectional performance differences and risk.

This study extends the existing literature on bank board governance in several ways. First, a large number of works on governance practices in non-financial firms ${ }^{3}$ find contrasting results and no clear-cut implication can therefore be drawn for the banking industry. Furthermore, the existing banking literature on emerging and developing countries has paid more attention to institutional, regulatory and macroeconomic determinants of bank performance (e.g., Berger et al., 2010; Caprio et al., 2007; Chen and Kao, 2011; Djankov et al., 2005; Macey and Maureen, 2003). Second, unlike other few studies on the banking industry (e.g., Adams and Mehran, 2012; Liang et al., 2013; Mateos

performance focus on observable diversity. We interchangeably use "diversity" and "heterogeneity" to refer to the same definition.

${ }^{2}$ By 2008 in Norway, for instance, at least $40 \%$ females to be hold on boards of publicly traded and large firms. This requirement is also adopted by Spain and France ( $40 \%$ by 2015 and 2017 respectively), Italian ( $30 \%$ by 2015 ), and the Netherlands ( $30 \%$ for each gender by 2016 ). In Asia, female constitutes only $4.7 \%$ of the board members while it is $12.5 \%$ in UK (Davies, 2011, 2014). Other countries may adopt voluntary standard to promote gender balance on board. Despite that many firms have adopted diversity training aiming at to promote understanding and respecting cultural diversity and eliminate the roadblocks due to a cultural diversity, its effectiveness, however, remains questionable (Guiterrez et al., 2000).

${ }^{3}$ For instance, Eklund et al. (2009) find a small and negative impact of gender on Swedish non-financial firms' investment performance. In contrast, using data on Spanish non-financial firms Campbell and Vera (2007) find a positive effect of gender on performance. Zhang (2007) finds that tenure and experience heterogeneity of top management of non-financial listed firms in China is negatively related to performance. 
de Cabo et al., 2012; Pathan and Faff, 2013) ${ }^{4}$, this paper considers not only a single measure of diversity (e.g. gender diversity), but also other diversity indices that could potentially influence performance (i.e. citizenship, age, experience, tenure, ethnicity, nationality, education level and type). Third, Adams et al. (2010) note that the vast majority of the literature on board characteristics mainly focuses on Anglo-American firms and hence studies of boards in non-Anglo-American firms is an understudied area. This is partly because only few firms from the latter provide information on board members to the public. But even when the information is available, previous works have mainly focused on a single dimension of diversity. For instance, in their work on US banks, Pathan and Faff (2013) investigate gender diversity but not the other dimensions. We go beyond by using several diversity dimensions, particularly ethnicity and professional background, by focusing on an emerging country. Our study provides evidence on how diversity of board members affects bank performance in a relatively weak shareholder protection environment as highlighted by Claessens and Yurtoglu (2013). To our knowledge, this study is the first comprehensive study looking into the impact of board diversity on bank risk. We consider the case of Indonesia which is the fourth populated country in the world (250 million) with more than 1,000 ethnic groups and 500 local languages, and with 121 commercial banks including 10 foreign banks, making it an ideal laboratory to, furthermore, avoid cross country heterogeneity. In a country with weak investor protection rights, which is the case of this study, board structure and its diversity might have stronger effects in mitigating various incentive problems. This study also adds to the growing body of literature which investigates whether bank performance and risk during the global financial crisis of 2007/2008 can be partly explained by corporate governance mechanisms (Adams and Mehran, 2012; Aebi et al., 2012; Beltratti and Stulz, 2012; Berger et al., 2012; Erkens et al., 2012; Fahlenbrach and Stulz, 2011). Moreover, in Asia, the less transparent process of nominating and appointing directors and scarce board evaluation increase the probability of poor-performance directors to be re-elected (OECD, 2013). From this perspective, boards with a balanced diversity, and therefore presumably less prone to collusion of their members, are expected to more easily mitigate the lack of appropriate and sound external evaluation processes.

\footnotetext{
${ }^{4}$ Mateos de Cabo et al., (2012) and Pathan and Faff, (2013) only consider gender diversity as the diversity measure in European and US bank, respectively. Hagedorf and Keasey (2012), however, use several diversity measures to test its impact on market gains (i.e. cumulative abnormal returns) from US banks' M\&As.
} 
Using 4200 individual year observations on the board of Indonesian bank including 21 ethnicities within the 2001-2011 period, we construct indicators of diversity in four dimensions (i.e. gender, ethnicity and nationality, professional experience and tenure, and education level and type) and find such factors to affect bank performance and risk. Specifically, our results show that diversity in professional background and education positively impacts performance but that stronger heterogeneity in ethnicity and nationality is detrimental by leading to higher risk taking. The rest of the paper is structured as follows. Section 2 shows how our work extends the current literature and provides a rationale for the tested hypotheses. Section 3 presents the data and the econometric specification and section 4 the results. Section 5 concludes.

\section{Related literature and research focus}

The board diversity literature is divided in various strands. The resource based theory argues that the board of directors (BOD) is a strategic resource by which a firm can get access to external sources such as funds, new skills or methods, and new opportunities. This theory is in line with human capital theory suggesting that every person has unique and useful characteristics. Hence, a heterogeneous board also allows more and richer information to flow into the firm which can benefit from a broader information network. A more diverse board is regarded as positive for the firm and its financial performance (Carter et al., 2010; Fang et al., 2012; van der Walt and Ingley, 2003). For non-financial firms, empirical studies have shown that heterogeneity is associated with positive outcomes such as more diverse perspective, higher creativity and innovation, and better results in terms of risk and/or audit management (e.g., Brown et al., 2002; Robinson and Dechant, 1997; Shrader et al., 1997). In the banking industry, however, studies using board size to capture a higher-resourced Board of Directors $(\mathrm{BoD})$ provide inconclusive results (e.g., Adams and Mehran, 2012; Andres and Vallelado, 2008).

Another large body of literature on board diversity is based on the principal-agency theory. Since the members of the board might have incentives to serve their own personal benefits and not those of shareholders, the board may need an independent oversight (Adams et al., 2010; Fama, 1980; Shleifer and Vishny, 1997). Also, to conduct effective monitoring and advising roles, boards accordingly need the appropriate mix of experience and capabilities that can be achieved through a more diverse board (e.g., Hillman and Dalziel, 2003) in the notion that a more diverse board will increase board independence (Carter et al., 2010; Carter et al., 2003). In contrast, (Adams and Mehran, 2012) find that 
board independence, which presumably is stronger as diversity increases, has no effect on bank performance.

Carter et al. (2010) argue that as a homogeneous group is built in a search of trust, any new member from the outside or from a different background might be considered as a threat. The addition of new a member might generate extra costs and reduce team cohesion and performance. Similarly, diversity could bring unintended consequences such as the lack of cooperation, inadequate qualification, and conflict of interest (Ferreira, 2010). Nevertheless, contingency theory postulates that such diversity may still be desirable in some types of organizations and depending on specific circumstances at different times (Boyd, 1990; Gabrielsson and Huse, 2004). In other words, when board heterogeneity results in better outcome (e.g. performance), it should be treated as imperative otherwise it should be reconsidered as unnecessary. For example, Pathan and Faff (2013) find that the excessive proportion of female on the board could adversely affect the possibility to catch more capable male directors. Such an effect is more pronounced for banks with low market power and smaller size.

Other studies argue that higher diversity could lead to negative outcomes (e.g., Ferreira, 2010; Mueller, 2003). To achieve optimal performance, the board not only needs better access to relevant information that could be brought by outside members, but also a timely and efficient decision making process. Heterogeneous board may imply a trade-off between higher costs in terms of longer decision-making and the lower external costs associated with better information access (Mueller, 2003). Elron (1997) observes that cultural heterogeneity and member diversity do not correlate with group cohesion although the group cohesion is positively related to performance. This partly explains the fact that a heterogeneous board does not necessarily lead to better performance. In other words, while a more heterogeneous board might offer higher information efficiency it can hinder efficient decision-making. A heterogeneous board might also be superior in knowledge about the business environment and about other firms but does not necessarily come with superior knowledge about the firm itself. Other studies find that homogeneous teams outperform heterogeneous ones (e.g., Baranchuk and Dybvig, 2009; Hambrick et al., 1996; Knight et al., 1999; Treichler, 1995) ${ }^{5}$.

\footnotetext{
${ }^{5}$ Hambrick et al., (1996) contends that diverse teams, based on educational, functional and tenure backgrounds, are found to be slower and less likely to respond competitors' actions. Baranchuk and Dybvig (2009) suggest such teams lack cohesiveness that potentially affects the group effectiveness.
} 
Similarly, previous studies find little evidence of any impact of gender heterogeneity on firm performance (see, e.g., Farrell and Hersch, 2005; Liang et al., 2013; Terjesen et al., 2009; Terjesen and Singh, 2008).

Other studies have investigated other types of diversities. For instance, Monks and Minow (2011) argue that the expertise and occupational characteristics affect the boards' ability to effectively monitor and lead the firm. Looking into S\&P 500 industrial firms, Anderson et al. (2004) find that independent director characteristics (i.e. executive, retired, and academic background ) is related to a lower cost of debt. Other researches also highlight that minority group members (e.g. ethnic minority) diverge in decision making (Westphal and Milton, 2000), and that their presence is positively associated with returns on assets and returns on equity (Erhardt et al., 2003), and Tobin's Q (Carter et al., 2003).

In the case of developing or emerging countries such issues can be further exacerbated by the lack of appropriate institutional environment and protection for shareholders. For instance, Khanna and Yafeh (2007) argue that the lack of transparency related to management structures often lead to worse corporate governance and expropriation of minority rights. Because ownership is often largely concentrated, the potential conflicts between majority and minority shareholders are generally more pronounced (e.g., Claessens and Fan, 2002; Claessens and Yurtoglu, 2013; Djankov et al., 2008). For this reason, Saito and Dutra (2006) argue that minority shareholders and the firm itself suffer from a dependency problem between the controlling shareholder and the board of directors. Hence, the structure and composition of board structure in such countries is crucial and there is a need for an appropriate mix (i.e., diversity) of board members combined with other governance mechanisms (e.g., independent directors, presence of block holders, et cetera).

There is much less research regarding the impact of board diversity on bank risk. Previous studies which are largely dedicated to non-financial firms suggest that women are more risk-averse than men and that their presence is associated with lower risk taking (e.g., (e.g., Jianakoplos and Bernasek, 1998; Mateos de Cabo et al., 2012). Adam and Ferreira (2004) argue that such a relationship might not be due to differences in gender risk aversion but, rather to a preference towards risk in homogenous environments -i.e. higher risk in a less diverse (fewer women) board. In contrast, Berger et al. (2012) provide evidence that a higher proportion of female executives in German banks leads to riskier activities. Another study by Harjoto et al. (2014), however, finds that industrial firms with 
a more diverse board take less risk. Board diversity significantly curbs excessive risk taking for firms with above industry median risk taking activities.

A study by May (1995) suggests that older directors are more reluctant to take risk because of the higher amount of their wealth vested in the firm while younger directors are more eager to undertake innovative high-growth investments. Similarly, Berger et al. (2012) and Grable et al. (2009) find that younger teams are associated with higher risk taking. Given that a board is commonly composed of persons with different ages and that different ages imply different working experience, the impact of experience and also that of tenure diversity on risk are still unclear. Previous studies also consider the relationship between education level and risk to be either positive (Bertrand and Schoar, 2003; Grable, 2000) or negative (Graham and Harvey, 2001). Hence, how diversity could affect risk on this behalf remains an open question.

\subsection{The Indonesian institutional setting and bank corporate governance}

Like others countries in Asia, Indonesia has experienced an important economic growth until the 1997 financial crisis hit the region. The crisis called for the review of the existing corporate governance characteristics such as a very high degree of ownership concentration by family/business groups (e.g., Claessens et al. (2000) note that $71.5 \%$ of listed companies are owned by family/business groups), excessive government-led growth (Hanazaki and Liu, 2007), lack of transparency and control (Zhuang et al., 2000), and poor legal protection of investors (Obata, 2003). Regarding the Indonesian banking sector, studies reveal that there is over reliance on external (foreign) funding in the corporate sector that in turn leads to highly vulnerable positions and higher credit risks ${ }^{6}$. In addition, ineffective supervision by the two-tier board system and by creditors, as in Indonesia, has also contributed to the crisis (Asian Development Bank, 2000; Claessens and Yurtoglu, 2013; Zhuang et al., 2000). In the post-crisis period (1997-2000), 61 banks were closed, 54 taken-over, and 39 recapitalized.

An explicit limited deposit guarantee (i.e. up to Rp20 millions per account of deposits) was introduced at the end of 1997 but this failed to prevent bank runs. In January 1998, the government of Indonesia (GoI) introduced a blanket guarantee covering all commercial banks' liability in all currency denominations which then was revised to cover

\footnotetext{
${ }^{6}$ On 14 August 1997, Bank Indonesia abolished the intervention bands (managed-float regime) on Indonesian rupiah and moved to free-float regime. At that time, the private sector hold US\$78.1 billion of largerly unhedged offshore borrowing with the rupiah deeply depreciated, i.e. Rp4,650 (at the end of 1997) to Rp16,000 per US\$ (in January 1998) (Batunanggar, 2002).
} 
up to Rp5 billions in 2006, Rp1 billions in the beginning of 2007, and gradually reduced to Rp 2 billion in 2008. In 2008, the Indonesian banking sector experienced a big shock due to capital outflows following the sub-prime mortgage crisis in the U.S. leading to an important local currency depreciation, a large drop in the stock exchange index $(>50 \%)$, and the activation of the Crisis Management Protocol (CMP).

Regarding the corporate governance of banks, the central bank has proposed the socalled Indonesia Banking Architecture in 2005 as the roadmap for the next 5-10 years where one of the six targets is the establishment of good corporate governance in order to strengthen the performance of banks. Accordingly, Bank Indonesia (BI) has introduced numerous regulations to promote good governance practices such as imposing a fit and proper test on bank board members, requiring a compliance director, and the introduction of independent board members (i.e., Bank Indonesia (BI), 2006). In the view of board diversity, however, there are only few regulations to address or encourage more diverse backgrounds of board members despite the fact that promoting diversity has proliferated particularly in the political context such as $30 \%$ gender representation.

One particular regulation in the banking sector, for instance, stipulates that to hold the position of regional bank director a candidate should hold at least a bachelor degree (S1), a 15-year experience in the financial institution, and should be at most 55 years old at the time of the appointment (Menteri Dalam Negeri, 1999). The regulation on fit and proper test for the candidate as stipulated by the regulation (PBI No.12/2010) sets the general procedures and the targets of this test but does not specify detailed requirements for the candidate. Furthermore, it only suggests that the majority (more than 50\%) of board members must have at least five years of banking experience. In relation to this, the current debate is on setting a minimum number of years of experience in the financial sector for board member candidates.

\section{Data, variables, and empirical setting}

\subsection{Sample}

To perform our analysis, we use data from banks operating in Indonesia where there are 121 commercial banks and 1,682 rural banks (Bank Indonesia, 2011) serving more than 240 million people and more than 300 ethnic groups ${ }^{7}$. However, because data on boards' profiles are rarely available our sample is limited to 38 commercial banks over the

\footnotetext{
${ }^{7}$ Cencus 2010 by Indonesia Central Bureau of Statistics (BPS), however, reveals there are 1.128 ethnic groups that inhabit throughout the country and speak in more than 200 different local languages. There are more than 10 ethnic groups with its population more than one million.
} 
2001-2011 period. Our sample banks nevertheless represent approximately $82.6 \%$ of aggregate bank assets during the period under study with 418 bank-year observations covering approximately 4200 individual-year observations and more than 21 ethnic groups. This includes state-owned banks, private banks and regional banks. We exclude rural banks because such banks operate in a very limited area and are very small. Due to data availability, we only have two foreign banks in our sample.

To construct our measures, we manually excerpt the profile of board members mainly from the annual reports, banks' web sites, and other relevant sources such as Indonesia Banking Institutes and news releases. Hence, when the first two sources do not provide sufficient information (e.g., the bank only provides the name and working experience), we go to the next sources until we find the necessary information. For banks which are subsidiaries or owned by business groups, we are able to collect more detailed profiles of board members in the affiliated firm's reports/websites than in the bank's report itself to complete the data. We also retrieve data from particular columns of banking magazines and newspapers that publish bankers' profiles including information on their families and their life.

\subsection{Variables Measurement}

\subsubsection{Measuring diversity}

Generally, existing studies measure board diversity (heterogeneity) using two approaches -individual versus composite indices. In this study, we identify seven individual measures namely gender, nationality, ethnicity, experience, tenure, education level, and education type. We focus on our composite diversity measures based on ethnicity and nationality (Ethnog), experience and tenure (Professional), and education level and type (Education) in addition to gender diversity. Nevertheless, for robustness, we also use individual measures which we discuss later. Individual and composite measures are defined as follows.

To account for gender diversity, we calculate the proportion of women (Female) on the board as a proxy for gender diversity (see Appendix A for detailed definition). Previous studies on diversity largely focus on gender as the main variable and show that stronger presence of women can either positively (e.g., Bilimoria, 2000; Erhardt et al., 2003; Mattis, 2000), negatively (Eklund et al., 2009), or non-significantly (Rose, 2007) impact on performance. Female directors commonly have higher expectations regarding their 
responsibility leading to a better monitoring of managers by the board. Looking into European commercial banks, Quack and Hancké (1997) show that the proportion of women among managers decreases as the management level increases. Further they observe that while women accounted for half of the employees, only $16 \%$ of them seat on managerial positions. Based on a sample of 612 European banks, Mateos de Cabo et al. (2012) conclude that the proportion of women on the board increases in lower-risk, larger boards and growth-oriented banks. In another study, Bellucci et al. (2010) find that female business owners face tighter credit availability and that Italian female loan officers are more risk-averse as they tend to restrict credit availability to new borrowers.

Studies on ethnic diversity have been less pronounced and virtually limited to certain countries due to ethnic characteristics in each country ${ }^{8}$. Cox (2001) examine the quality of ideas generated by homogeneous groups of Whites and other groups comprising Asian Americans, Blacks, White, and Hispanics. They conclude that ideas generated by ethnically diverse groups were rated on average $11 \%$ higher than those of homogeneous groups both in terms of feasibility and effectiveness. Nevertheless, Carter et al. (2010) do not find any relation between ethnic heterogeneity on the board and S\&P 500 firms' performances. We measure ethnic heterogeneity (Ethnic diversity) based on the ethnicity of bank directors (e.g., Chinesse, Javanesse, Sundanesse, Batak, Malay, Caucasian, Minahasa, Bugis, Minang et cetera). We note that there are more than 1,000 ethnic groups in Indonesia but we identify 21 ethnics that appear on the director profiles of this study. To compute ethnic diversity, we use the Blau's index which is similar to inverse of the Herfindal-Hirschman index (HHI) and formulated as follows ${ }^{9}$ :

$$
\text { Diversity index }=1 / \sum_{\alpha}^{\mathrm{n}}\left(\frac{\mathrm{N} \alpha}{\mathrm{NT}}\right)^{2}
$$

where $\mathrm{N} \alpha$ represents the number of directors in the $\alpha^{\text {th }}$ category and NT represents the total number of directors. A higher value taken by the index represents a more diverse group.

\footnotetext{
${ }^{8}$ Studies regarding the ethnicity might not be conducted in a country due to too homogeneous or because such data is not available for some reasons. In Spain, for example, ethnic diversity is not a big issue since White Spain constitutes around $98 \%$ of the Spanish population (Aja et al., 2000) in Campbell and Vera, 2008). Another study by Simpson et al., (2010) only examines to what extent the ethnic diversity (i.e. Caucasian, African-American, Hispanic, and Asian) on S\&P boards in 2007 with regard to their gender.

${ }^{9}$ We adopt Blau's index of heterogeneity as Harrison and Klein (2007). This measures diversity as the degree of heterogeneity among board members with respect to a certain attribute for example gender or ethnicity. It is said to be an ideal measure of heterogeneity because it meets the four criteria that have been laid out for a good measure of diversity: it has a zero point to denote complete homogeneity, larger number indicate greater diversity, the index does not assume negative values, and the index is not unbounded (Harrison and Sin, 2006).
} 
Following Fang et al. (2012), for example, ethnic diversity $=1 /\left[\right.$ Chinese ratio ${ }^{2}+$ Javanese $^{2}$ ratio $^{2}+$ Sundanese ratio $^{2}+$ Batak ratio $^{2}+$ Malay ratio $^{2}+$ Minang ratio $^{2}+$ Javanese ratio $\left.^{2}\right]$.

Globalization and deregulation in banking have broadened the access of banks to various resources including foreign board members. One can argue that foreign board members will not only provide broader networks but also, bring international perspective and experience to the recruiting banks. The bank could get advice on how the expansion to foreign markets should be established or how foreign banks operate in domestic markets. Liang et al. (2013) argue that foreign directors might bring new technology and managerial techniques, leading to better performance. In contrast, Masulis et al. (2012) find that foreign independent directors of the U.S. S\&P-1500 firms is related to a higher compensation, lower sensitivity of CEO turnover to performance and poorer firm performance. To account for this effect, we use Blau's index, based on the number persons who are foreign citizens and the others who are Indonesian. Each number is then divided by the total number of directors to compute the ratio of foreign directors (Foreign ratio) and the ratio of Indonesian directors (Indonesian ratio). Following Fang et al. (2012),

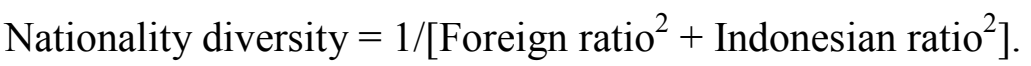

To consider ethnicity and nationality diversity as discussed above we build a variable named Ethnog diversity defined as the average of two components: Ethnic diversity and Nationality diversity. Hence Ethnog diversity $=$ (Ethnic diversity + Nationality diversity)/2.

The resource dependent approach and human capital theory suggest that education and training can improve the value of people allowing them to have better knowledge and skills to achieve organizational goals. Hence, education heterogeneity should broaden boards' perspectives and improve decision making. Simons et al. (1999) find that both educational and cognitive diversity are positively correlated with organizational performance. In this study, following Anderson et al. (2011), we measure education heterogeneity based on depth (education levels) and breadth (education types). For depth, we use the Blau index (Education level diversity) based on the highest degree of directors i.e., whether he/she has no bachelor degree (S0), bachelor degree (S1), master degree (S2), or doctoral degree/beyond (S3). We calculate the proportion of members in each educational level and measure the Blau index as formulated in Eq.(1). Specifically, education level diversity $=1 /\left[\mathrm{S} 0 \mathrm{ratio}^{2}+\mathrm{S} 1 \mathrm{ratio}^{2}+\mathrm{S} 2 \mathrm{ratio}^{2}+\mathrm{S} 3 \mathrm{ratio}^{2}\right]$. While for 
breadth (Education type diversity), we divide the number of board members with education background other than economics, finance, accounting, and business by total board members. A higher figure indicates a more diverse board based on this background. To account for both diversities, we then measure education diversity as the average of education level and education type diversities.

Tenure essentially represents the length of time (e.g. months, years) a person has been sitting on the board and can be related to the business experience of a director. Hence, a longer-tenured director should lead to better performance. An increase in board tenure, however, is not only related to greater commitment but also more inflated CEO salaries (Vafeas, 2003). Others argue that a longer tenure may reflect a greater influence of bank managers over directors' opinions and decisions and bring an adverse impact to the firm (Anderson et al., 2004). In this study, tenure diversity (Tenure diversity) is measured by the standard deviation of tenure periods of board members. Next, working experience is important for directors to work effectively with other team members and to make better decisions. We measure the working experience by the length of time (years) a person has been working in the banking industry. This variable reflects the accumulated hand-on experiences gained from the banking industry leading to higher human capital that in turn should allow the bank to achieve better performance. To estimate experience diversity (Experience diversity), we use the standard deviation of the years of banking experience. We compute the average of Tenure diversity and Experience diversity and name it Professional diversity.

\subsubsection{Measuring performance and risk}

This study uses several proxies to measure bank performance. First, we introduce the return on assets (ROA) of the bank that is defined as profits before taxes divided by its average assets (the mean value of bank's assets at time $t$ and $t-1$ ). We also consider the return on equity (ROE) defined as the ratio of profits before taxes to the average equity (the mean value of outstanding equity at time $t$ and $t-1$ ). Alternatively, we use two other measures of performance: (1) risk-adjusted return on assets (adjusted ROA) that is the ratio of ROA to its standard deviation calculated from the last three observations for the respective year; (2) risk-adjusted return on equity (adjusted ROE) that is the ratio of ROE to its standard deviation calculated from the last three observations for the respective year (i.e., $t, t-1$ and $t-2$ ). 
In addition to the standard deviation of returns (SDROA and SDROE) to capture risk, we consider the Z-score (Goyeau and Tarazi, 1992; Lepetit et al., 2008; Barry et al., 2011). This score is defined as (ROA + EA) / SDROA, where ROA is the bank's return on assets, EA is the ratio of equity to total assets. We also split the Z-score into its two components Z-score 1 defined as ROA divided by SDROA and Z-score 2 which is EA divided by SDROA. Z-score 1 is expected to measure asset risk and Z-score 2 leverage risk.

\subsubsection{Control variables}

The size of the bank can be related to the bank's performance since a larger bank may be able to achieve cost reduction due to economies of scale. Hence, we consider the logarithm of total assets (e.g., Berger et al., 2005) to control for this dimension (Size). As size increases, banks may enjoy better portfolio diversification benefits leading to a negative relationship with risk. On the other hand, by increasing its size, a bank could also benefit from To-Big-To-Fail (TBTF) safety net subsidies (De Nicolo, 2000). Following Pathan and Faff (2013), we also include the total capital ratio defined as banks' total equity divided by its total assets (Capital). A well-capitalized bank is less likely to default and hence its cost of funding might be lower possibly leading to higher profitability (Berger, 1995). Banks with higher level of capital are able to sustain loss events more easily and hence avoid failure. Bank capital also determines the level of risk that banks might be willing to take. As such, this ratio is expected to capture the bank's degree of risk aversion.

A bank listed on a stock exchange is expected to be more closely monitored and subject to stronger market discipline leading to better performance. Such a bank could also benefit from cheaper sources of funds. Following Liang et al. (2013), we include a dummy variable (Listed) that equals one (1) if the bank is listed and zero (0) otherwise. Publicly held banks should behave differently than their counterparts because they are subject to more stringent market discipline but at the same time they are able to raise additional equity at lower costs which allows them to invest in risky projects with higher returns. Hence, the effect of this variable is undetermined (Barry et al., 2011). We also use the loan to total assets ratio (Loan) to reflect the bank's strategy and its strong or weak focus on traditional intermediation activities (Lin and Zhang, 2009). On the one hand, banks with a lower loan to total assets ratio are less dependent on interest income and benefit more from diversification (DeYoung and Roland, 2001). On the other hand, because regulators allow banks to hold less capital against non-interest activities, financial leverage will be larger which may raise earning volatility further (Demirgüç-Kunt and Huizinga, 2010; DeYoung 
and Roland, 2001). Banks with a higher share of loans in total assets can be more risky since they are more exposed to credit risk and therefore earning volatility (Maudos and Fernández de Guevara, 2004). We further control for foreign ownership by considering a dummy variable (Foreign bank) which takes the value of 1 when foreign owners have stakes of at least 50\% and zero otherwise (Barth et al., 2004). The presence of foreign owners could lead to lower cost of financial intermediation (i.e. lower spreads or margins) and thus lower profitability (Beck et al., 2008; Claessens et al., 2001). Laeven (1999) argues that because foreign banks in South East Asia (i.e. Indonesia, Korea, Malaysia, the Philippines and Thailand) operate under more restrictions, particularly compared to state banks, they take less risk. We also consider if the bank is a member (subsidiary) of a business group by introducing a dummy variable (Business group) which takes the value of 1 if a bank belongs to a group and zero otherwise). A bank operating in a business group might be more inclined to serve the interests of its group and affiliated firms. Claessens and Fan (2002) argue that firms in a business group often deal with greater management and agency problems, resulting in resource misallocation and poorer performance. On the other hand, such firms may be able to access funding at a lower cost. Claessens and Fan (2002) also highlight that a firm's risk strategy in East Asia is not only influenced by its own characteristics (e.g., size, capital etc.) but also by group characteristics; group structure can be used to diversify risks internally. Eventually, to account for the global financial crisis of 2007/2008 (Crisis) we introduce a dummy variable that takes the value of 1 for year 2008 and zero otherwise. As Asian banks were not immediately affected by the crisis we do not consider 2007 to be a critical year but we also include it for robustness considerations and find similar results.

\subsection{Empirical Model}

We consider the following specification :

Performance or Risk $_{\mathrm{i}, \mathrm{t}}=\alpha_{0}+\beta_{1}$ Board Diversity $_{\mathrm{i}, \mathrm{t}}+\sum \beta_{\mathrm{i}}$ Controls $_{\mathrm{i}, \mathrm{t}}+\varepsilon_{\mathrm{i}, \mathrm{t}}$

where Performance represents bank performance measured by either ROA, ROE, riskadjusted ROA and risk-adjusted ROE. Risk is measured by either SDROA, SDROE, Zscore, Z-score 1, and Z-score 2. Board Diversity stands for the four categories of bank board heterogeneity that we consider in this study (i.e. Gender, Ethnog, Education, and 
Professional). Controls represents the matrix of control variables to account for bank characteristics and the financial crisis period.

Pathan et al. (2008) argue that empirical studies on board composition and performance suffer from endogeneity issues that partly come from the nature of the variables used in such studies. Board structure in a given year, for example, could be affected by the bank's performance in previous years. Hence, in their studies, Hermalin and Weisbach (2003), Adams et al. (2010), Carter et al. (2010), Anderson et al. (2011), Fang et al. (2012) use an instrumental variables/two-stage least-squares (IV/2SLS) specification. For this reason, we use the instrumental variables (IV) approach to deal with potential endogeneity as indicated by our reported tests in the following section ${ }^{10}$.

\section{Results}

\subsection{Descriptive Statistics}

Before we go further, we exclude the extreme observations (1\% lowest and $1 \%$ highest values) to deal with possible outliers. We also drop negative values of capital as this implies that the bank is technically in default. Table 1 presents several descriptive statistics for the variables used in this study. Panel A describes the performance measures, return on assets (ROA) and return on equity (ROE). The means of ROA and ROE during the 2001-2011 period are $2.2 \%$ and $18.5 \%$ respectively. Further examination reveals that both measures reach their lowest values in $2008(\mathrm{ROE}=14.3 \%)$ and $2009(\mathrm{ROA}=1.8 \%)$. We note that the average values of risk-adjusted ROA and risk-adjusted ROE are 5.4 and 5.1 respectively. The means of SDROA and SDROE are $1 \%$ and $9 \%$ respectively whereas those of Z-score, Z-score 1, and Z-score 2 are 9.9, 5.2, and 3.9 respectively.

\section{[INSERT TABLE 1 ABOUT HERE]}

As aforementioned, we calculate diversity measures for each bank every year from 2001 to 2011. We note (Table 2), on average, a considerable increase in professional diversity, followed by Ethnog diversity (i.e., the sum of ethnicity and nationality diversity). Education diversity increases until 2004-2005 and decreases to 1.13 in 2011. Female members, however, only constitute around 8\% (2001) to 10\% (2011) of board members.

\footnotetext{
${ }^{10}$ We utilize "xtivreg2" in Stata proposed by Schaffer (2010). It implements IV estimation of the fixedeffects and first-differences panel data models with possibly endogenous regressors.
} 
Panel B of Table 1 shows the bank board characteristics that are used to measure heterogeneity (diversity) of the board. To account for gender, we take the proportion of female (Female) on the bank's board. The mean of Female is close to 0.1 with a maximum value of 0.4 (or $40 \%$ ). The maximum number of women serving on a board is five persons.

As presented in the previous section, we calculate the composite index Ethnog diversity to represent the average index of diversity in ethnicity and nationality. The mean of this composite index is 2.2. Table 2 shows that Ethnog diversity continuously increases over the sample period, although slowly, suggesting that banks tend to appoint more persons from other ethnicities or foreign countries.

Professional diversity measures the diversity in terms of working experience in the banking sector and tenure period acquired by the board member. A higher index indicates the richness of banking experience and hence could lead to a better decision making. Based on our results, it has the average of 5.9 years with minimum of 1.9 and maximum of 9. We note that this variable also increase considerably during the period 2001-2011 (Table 2).

Education diversity, measured by the average value of diversity by education level and education type has a mean value of 1.2. Most of the board members hold a master or bachelor degree and almost every three of ten directors have a degree in fields other than economics or business.

Panel C presents the descriptive statistics of the control variables considered in our study. On average, the total assets (Assets) of our sample banks amount to 40.1 trillion rupiahs. The ratio of equity to total assets (Capital) has a mean of $18.8 \%$ with a minimum value of $8.6 \%$ and a maximum value of $77.1 \%$. Foreign ownership increases from 0.13 (13.2\%) in 2001 to $0.263(26.3 \%)$ in 2011 . Approximately $47 \%$ of the banks in our sample are listed on the stock exchange but only $29 \%$ in 2001 while more than $60 \%$ in 2011 . More than half of the banks (around $58.9 \%$ of our observations) belong to a business group.

\section{[INSERT TABLE 2 ABOUT HERE]}

\subsection{Univariate Analysis}

Table 3 presents the pair-wise correlation matrix between the considered variables. The proportion of female on the board is negatively correlated with ROA, ROE adjusted ROA and adjusted ROE in line with the view that under certain circumstances the presence 
of female -as an additional / tougher monitor- may lead to a negative net effect (Adams and Ferreira, 2009). Similarly, Ethnog diversity negatively correlates with performance.

\section{[INSERT TABLE 3 ABOUT HERE]}

Professional diversity is negatively correlated with ROA and ROE but positively with risk-adjusted ROA and risk-adjusted ROE. Education diversity is positively correlated with performance except for ROA. In terms of risk, we find that Ethnog diversity is positively correlated with SDROA and SDROE whereas the other diversity measures are negatively correlated with both of them. Ethnog diversity is also negatively related to all Z-zcore measures whereas the other diversity measures are positively correlated with them.

\subsection{Multivariate Analysis}

In this section we run regressions of performance measures -ROA, ROE, adjusted ROA, and adjusted ROE- on the diversity measures and control variables. To deal with possible collinearity issues we introduce our main diversity variables one after the other in the regressions. Note also that the composite indices proposed in this study (see Section 3.2) are expected to better deal with collinearity concerns. For instance, it might be argued that there is possible strong correlation between ethnic diversity and nationality diversity because an incoming foreign director mostly means that she/he belongs to a different ethnic group. Furthermore, a foreign member might bring longer banking experience increasing the professional diversity score. As a further robustness check, we alternatively use orthogonalized variables for the presumably correlated variables. We also examine regressions with individual diversity dimensions run separately.

As discussed above, studies on board structure and performance often suffer from endogeneity that partly comes from the nature of the investigated variable. Such endogeneity, for instance, occurs because board structure may be affected by the bank's previous performance or by other firm characteristics (Carter et al., 2010; Carter et al., 2003; Fang et al., 2012; Hermalin and Weisbach, 2003; Pathan, 2009). For instance, better performing banks are inclined to select more experienced board members. We check for endogeneity by running the Durbin Wu-Hausman Chi-sq test with the null hypotheses that the diversity variable is exogenous. The tests generally report that the diversity variables are endogenous except for model (1). Table 4 reports the results of IV/2SLS regressions with ROA, ROE, adjusted ROA, and adjusted ROE as the dependent variables. 
Except for model 5 (ROE), our results show that almost all of the coefficients of gender diversity (Female) are not significant in our models. These results are in line with those of Terjesen and Singh (2008) and Rose (2007) who find that women have little impact when sitting on the board in contradiction with the findings of Erhardt et al. (2003). Despite the argument that a gender-diverse board is a tougher monitor, the net effect of gender heterogeneity (i.e. Female) is likely to disappear supporting the findings of Adams and Ferreira (2009) and Carter et al. (2010). This suggests that in the perspective of the contingency theory, such additional monitoring might be counterproductive. Also, there is a possibility that banks appoint female directors only to follow the trend of inclusion of women and ethnic minorities on the board. Our sample allows us to examine diversity based on ethnicity and nationality of the board members (Ethnog diversity). Table 4 reports negative coefficients of Ethnog diversity in all the models (ROA, ROE, adjusted ROA, and adjusted ROE). This is surprising because the board could presumably get more benefits from this diversity. This effect is economically significant. For instance, an increase of one standard deviation in this diversity measure is associated with decreases in ROA by $1.11^{11}$, ROE by -0.52 , adjusted ROA by -0.39 , and adjusted ROE by -1.51 . In other words, Ethnog diversity is not only related to lower performance, but also simultaneously to higher risk with a greater increase in risk, leading to lower risk-adjusted returns $^{12}$. Our results are somewhat different from those of Carter et al. (2010) who finds no significant link between U.S. S\&P 500 firms' performance and the presence of ethnic minority directors and foreign directors. Furthermore, despite the fact that there are hundreds of types of ethnicities in Indonesia, bank boards are commonly dominated by persons belonging to a limited number of ethnic groups. Theoretically, ethnic heterogeneity on the board would allow them to better understand their customers and hence deliver better services. In practice, ethnicity diversity, if not well managed, may become a burden for board members because they often bring different values and norms that might be difficult to coordinate. Ethnic diversity might indicate diversity in other terms such as language, custom, behavior or even the specific perspective of certain ethnic

\footnotetext{
${ }^{11}$ To obtain this value, we calculate: $\triangle \mathrm{ROA}=$ [one standard deviation of Ethnog diversity (Table 1$) *$ the coefficient of this variable (Table 4)] / mean of ROA (Table 1). Hence, for $\triangle$ ROA $=[0.937 *-0.0265] / 0.022=$ -1.108 . For $\Delta \mathrm{ROE}=[0.937 *-0.102] / 0.185=-0.517$, and so on. The economic significance of other variables are calculated with the same method.

${ }^{12}$ For example, we also regress a default risk measure, the Z-score and its two-components as in Barry et al., (2011) and find that Ethnog diversity is also related to lower Z-scores (higher default risk).
} 
groups on conducting business activities. Working with persons belonging to different ethnic groups could pose challenges and not necessarily lead to better performance. Regarding the presence of foreign members on the board, although their involvement presumably brings a broader international exposure, a weak knowledge of local market characteristics might outweigh the expected benefits. Our results supports Masulis et al. (2012) who find that foreign directors often reduce the board's effectiveness leading to greater agency problems and poorer performance.

Next, the coefficient of professional diversity is positive in all models, implying that an increase in professional diversity is likely to lead to higher performance. For instance, an increase in professional diversity by one standard deviation is associated to an increase of 0.55 and 0.21 times the current ROA and ROE respectively. Unlike Ethnog diversity, professional diversity is related to lower SDROA and SDROE. Hence, the effect of this type of diversity is economically more important when considering income volatilityadjusted performance as measured by risk-adjusted ROA and risk-adjusted ROE; an increase in professional diversity by one percent is associated with an increase in riskadjusted ROA of 1.37 and risk-adjusted ROE of 0.62 times the current levels. Note that professional diversity is composed by diversity in working experience in the banking sector and of tenure periods. Longer experience in the banking sector should lead to higher capability in managing a bank. Hence, in the perspective of the human capital theory, the presence of more experienced persons should lead to better decision making as supported by our results. Also, when we consider the second component (tenure period), a longer tenure may allow board members to learn from each other and exercise more skills. Our results support this argument.

The importance of education and training has been advocated particularly by the proponents of the resource dependent and human capital theories. With regard to education, our results show that education diversity is positively related to performance. All of the impacts on performance are significant despite that education diversity is only associated with risk-adjusted performance measures at the 10 percent significance level. Economically, an increase in education diversity by one standard deviation is related to an increase of ROA, ROE, adjusted ROA, and adjusted ROE by $0.58,1.19,0.53$, and 0.63 of the existing level respectively (see model 4 and model 8 of Table 4).

Regarding control variables, we find Size to have little impact on ROA and ROE; it is only significant in model (1) and model (2). It nevertheless significantly and positively correlates with risk-adjusted ROA and risk-adjusted ROE. Highly capitalized banks are 
likely to have a higher ROA and risk-adjusted ROA but a lower ROE. Such banks might be benefiting from lower funding costs. The coefficient of Loan is mostly negative for ROE in all models and for ROA in model (3). The coefficient is positive for risk-adjusted ROA.

Foreign ownership has a negative impact on risk-adjusted ROA and risk-adjusted ROE and little impact on ROE and ROA. Ceteris paribus, being listed on the stock exchange is associated with higher risk-adjusted ROE and banks belonging to a business group generally exhibit higher performance possibly because they benefit from better funding opportunities and/or support from their group.

With regard to risk, we find that the inclusion of a larger number of female members on the board is related to lower risk, particularly with regard to SDROA and SDROE (see Table 5). This is in line with previous studies (see, e.g., Barber and Odean, 2001; Jianakoplos and Bernasek, 1998; Mateos de Cabo et al., 2012). Economically, an increase in the ratio of female board members by one standard deviation reduces SDROA and SDROE by 71 and 14 percent respectively. In all models, Ethnog diversity is linked to higher return volatility (SDROA and SDROE) and higher default risk (Z-score, Z-score 1, and Z-score 2). For instance, an increase in Ethnog by one standard deviation is associated with approximately a 10 percent increase in SDROA and SDROE. Our results report that banks with professionally-diverse boards are likely to take less risk. Lastly, banks with more education diversity on the board exhibit higher returns variability, supporting Graham and Harvey (2001).

\section{[INSERT TABLE 5 ABOUT HERE]}

Bank size (measured by total assets) is negatively related to risk, suggesting that the risk diversification hypothesis is more effective than the moral hazard hypothesis (TBTF). Banks with a higher proportion of loans in total assets are those with lower risk, supporting the conjecture that such banks might benefit from more stable earnings.

\subsection{Robustness checks: alternative measurements and models}

We go further by conducting tests to examine the consistency of our results with those obtained with a more extensive breakdown of board diversity measures. Specifically, we separately consider the impact of gender (Female), nationality (National diversity), 
ethnicity (Ethnic diversity), experience (Experience diversity), tenure (Tenure diversity), education level (Education level diversity), and education type (Education type diversity) The results are reported in Table 6 and Table 7 for performance and risk respectively. On the whole our main results remain unchanged.

\section{[INSERT TABLE 6 and TABLE 7 ABOUT HERE]}

To check for further robustness, we run regressions with alternative performance measures namely the net interest margin (NIM) defined as net interest income divided by average earning assets and the ratio of operating expenses to operating income (OEOI). These ratios are frequently used as alternative measures of bank performance. We report the results in Table 8.

\section{[INSERT TABLE 8 ABOUT HERE]}

The coefficients of Female in both models show that the presence of women on the board is related to better performance -i.e. higher NIM but only at the ten percent significance level and lower OEOI in line with the argument of stronger monitoring. We do not find any significant impact of Ethnog diversity on NIM. Nevertheless, it has a positive impact on OEOI.

Table 8 reports that professional diversity is associated with higher NIM and lower OEOI, confirming that such diversity is associated with better performance. Consistently, higher education diversity leads to higher NIM and lower OEOI. These results confirm the findings obtained in the previous section.

In addition, we run regressions by excluding certain variables to deal with possible multicollinearity issues. First, we drop foreign bank from our models because it is considerably correlated with Ethnog diversity. This correlation is naturally understandable considering that banks owned by foreign investors are more likely to appoint foreign board members. Second, in our sample, around $60 \%$ of group-member banks are also listed on the stock exchange (the correlation coefficient between Listed and Business Group is equal to 0.36). Hence, we exclude Business group from the regressions. Next, we also exclude Listed because listed banks are more likely to be larger banks. On the whole our main results remain unchanged ${ }^{13}$. Alternatively, we orthogonalize Foreign bank, Business group and Listed with respect to Size. Again, our main findings remain the same.

\footnotetext{
${ }^{13}$ For brevity, we do not report all the results which are available on request.
} 


\section{Conclusion}

Board structure has received an increasing attention by researchers, regulators and practitioners. Specifically, the presence of board members with various characteristics (e.g., experience, tenure, education, gender, nationality, and ethnicity) is expected to affect performance through various channels. On the one hand board diversity is expected to enrich decision making process leading to better performance. On the other hand, diversity could become a burden to integrate and coordinate different views leading to poorer performance.

We conduct our study in one of the most fast-growing yet very diverse country: Indonesia. We look into the board characteristics of 38 commercial banks in Indonesia that represent approximately $80 \%$ of the country's banking industry and cover the 2001-2011 period. This allows us to consider approximately 4200 individual-year observations and more than 21 ethnic groups. The results, obtained from IV/2SLS models show that female presence does not strongly impact performance and that the presence of more diverse ethnic groups is associated with lower performance. Professional diversity that measures diversity in working experience and tenure periods is linked to higher performance. Lastly, education diversity has a positive and significant impact on performance.

Furthermore, female presence has a negative impact on risk. Banks with diverse nationalities and ethnic groups on the board exhibit higher risk whereas those with higher professional diversity take less risk. Education diversity leads to higher income volatility and leverage risk.

On the whole, our results show that looking into the diversity of board members is crucial for a better understanding of bank performance, supporting Claessens and Yurtoglu (2013) who argue that board composition is an important mechanism in emerging markets where corporate governance codes are relatively weak. The process of appointing board members should account for a higher degree of professional and education diversity as banks face more diverse environments. However, banks have to carefully mitigate the adverse impact of ethnic and nationality diversity. Our results suggest that to some extent the benefits of such diversity do not outweigh the adverse effects caused by the inability to integrate such differences and to mitigate potential conflicts among board members.

On the whole, our findings suggest that the design and choice of board structure is critical in the Indonesian banking sector which is undergoing a notable improvement in corporate governance mechanisms as in other emerging countries. For example, regulators are aiming to set a minimum of ten-year experience for director candidates. Regulatory 
bodies and stakeholders should also limit the possible downside effect while promoting more diverse boards. As argued by Ferreira (2010) firms should be able to identify the trade-offs of diversity in order to increase their performance and values. Therefore, drawing any firm conclusion on how board characteristics will eventually affect performance and risk is hazardous. Nevertheless, our study sheds light on specific factors and possible tracks for future policies aimed at improving board effectiveness and efficiency. 


\section{References}

Adams, R.B., Ferreira, D., 2004. Gender diversity in the boardroom. European Corporate Governance Institute, Finance Working Paper 58.

Adams, R.B., Ferreira, D., 2007. A Theory of Friendly Boards. The Journal of Finance 62, 217-250.

Adams, R.B., Ferreira, D., 2009. Women in the boardroom and their impact on governance and performance. Journal of Financial Economics 94, 291-309.

Adams, R.B., Hermalin, B.E., Weisbach, M.S., 2010. The role of boards of directors in corporate governance: A conceptual framework and survey. Journal of Economic Literature 48, 58-107.

Adams, R.B., Mehran, H., 2012. Bank board structure and performance: Evidence for large bank holding companies. Journal of Financial Intermediation 21, 243-267.

Aebi, V., Sabato, G., Schmid, M., 2012. Risk management, corporate governance, and bank performance in the financial crisis. Journal of Banking \& Finance 36, 3213-3226.

Anderson, R.C., Mansi, S.A., Reeb, D.M., 2004. Board characteristics, accounting report integrity, and the cost of debt. Journal of Accounting and Economics 37, 315-342.

Anderson, R.C., Reeb, D.M., Upadhyay, A., Zhao, W., 2011. The economics of director heterogeneity. Financial Management 40, 5-38.

Andres, P.d., Vallelado, E., 2008. Corporate governance in banking: The role of the board of directors. Journal of Banking \& Finance 32, 2570-2580.

Asian Development Bank, 2000. Corporate Governance and Finance in East Asia: A consolidated report. Asian Development Bank (ADB), Manila, Philippines.

Bank Indonesia (BI), 2006. Peraturan Bank Indonesia tentang pelaksanaan good corporate governance bagi bank umum, 8/4/PBI/2006, Jakarta, Indonesia.

Bank Indonesia (BI), 2010. Peraturan Bank Indonesia tentang uji kemampuan dan kepatutan (Fit and proper test), 12/23/PBI/2010, Jakarta, Indonesia.

Baranchuk, N., Dybvig, P.H., 2009. Consensus in Diverse Corporate Boards. Review of Financial Studies 22, 715-747.

Barber, B.M., Odean, T., 2001. Boys will be Boys: Gender, Overconfidence, and Common Stock Investment. The Quarterly Journal of Economics 116, 261-292.

Barry, T.A., Lepetit, L., Tarazi, A., 2011. Ownership structure and risk in publicly held and privately owned banks. Journal of Banking \& Finance 35, 1327-1340. 
Barth, J.R., Caprio Jr, G., Levine, R., 2004. Bank regulation and supervision: what works best? Journal of Financial Intermediation 13, 205-248.

Batunanggar, S., 2002. Indonesia's banking crisis resolution: Lesson and the way forward, The Banking Crisis Resolution Conference - CCBS, London.

Beck, T., Demirguc-Kunt, A., Laeven, L., Levine, R., 2008. Finance, Firm Size, and Growth. Journal of Money, Credit and Banking 40, 1379-1405.

Bellucci, A., Borisov, A., Zazzaro, A., 2010. Does gender matter in bank-firm relationships? Evidence from small business lending. Journal of Banking \& Finance 34, 2968-2984.

Beltratti, A., Stulz, R.M., 2012. The credit crisis around the globe: Why did some banks perform better? Journal of Financial Economics 105, 1-17.

Berger, A.N., 1995. The Relationship between Capital and Earnings in Banking. Journal of Money, Credit and Banking 27, 432-456.

Berger, A.N., Clarke, G.R.G., Cull, R., Klapper, L., Udell, G.F., 2005. Corporate governance and bank performance: A joint analysis of the static, selection, and dynamic effects of domestic, foreign, and state ownership. Journal of Banking \& Finance 29, 21792221.

Berger, A.N., Hasan, I., Zhou, M., 2010. The effects of focus versus diversification on bank performance: Evidence from Chinese banks. Journal of Banking \& Finance 34, 14171435 .

Berger, A.N., Kick, T., Schaeck, K., 2012. Executive board composition and bank risk taking. Deutsche Bundesbank Research Centre Papers 3.

Bertrand, M., Schoar, A., 2003. Managing with style: The effect of managers on firm policies. The Quarterly Journal of Economics 118, 1169-1208.

Bilimoria, D., 2000. Building the Business Case for Women Corporate Directors, in: Burke, R., Mattis, M. (Eds.), Women on Corporate Boards of Directors. Springer Netherlands, pp. 25-40.

Boyd, B., 1990. Corporate linkages and organizational environment: A test of the resource dependence model. Strategic Management Journal 11, 419-430.

Brown, D.A.H., Brown, D.L., Anastasopoulos, V., 2002. Women on boards: Not just the right thing ... but the 'bright' thing. The Conference Board of Canada, Canada.

Campbell, K., Mínguez-Vera, A., 2008. Gender diversity in the boardroom and firm financial performance. Journal of Business Ethics 83, 435-451. 
Caprio, G., Laeven, L., Levine, R., 2007. Governance and bank valuation. Journal of Financial Intermediation 16, 584-617.

Carter, D.A., D'Souza, F., Simkins, B.J., Simpson, W.G., 2010. The Gender and Ethnic Diversity of US Boards and Board Committees and Firm Financial Performance. Corporate Governance: An International Review 18, 396-414.

Carter, D.A., Simkins, B.J., Simpson, W.G., 2003. Corporate Governance, Board Diversity, and Firm Value. Financial Review 38, 33-53.

Chen, A., Kao, L., 2011. Effect of collateral characteristics on bank performance: Evidence from collateralized stocks in Taiwan. Journal of Banking \& Finance 35, 300-309. Claessens, S., Demirgüç-Kunt, A., Huizinga, H., 2001. How does foreign entry affect domestic banking markets? Journal of Banking \& Finance 25, 891-911.

Claessens, S., Djankov, S., Lang, L.H.P., 2000. The separation of ownership and control in East Asian Corporations. Journal of Financial Economics 58, 81-112.

Claessens, S., Fan, J.P.H., 2002. Corporate governance in Asia: A survey. International Review of Finance 3, 71-103.

Claessens, S., Yurtoglu, B.B., 2013. Corporate governance in emerging markets: A survey. Emerging Markets Review 15, 1-33.

Cox, T., 2001. Creating the multicultural organization: A strategy for capturing the power of diversity, 1st ed. Jossey-Bass.

Davies, L., Ducas, A., Mackenzie, A., Parker, S.J., Casserley, D., Vinnicombe, S., Bott, S., 2011. Women on boards. The Women on Boards Steering Board, UK, London.

Davies, L., Ducas, A., Mackenzie, A., Parker, S.J., Casserley, D., Vinnicombe, S., Bott, S., 2014. Women on boards: Davies review - Annual report 2014.

De Nicolo, G., 2000. Size, charter value and risk in banking: an international perspective. International Finance Discussion Papers.

Demirgüç-Kunt, A., Huizinga, H., 2010. Bank activity and funding strategies: The impact on risk and returns. Journal of Financial Economics 98, 626-650.

DeYoung, R., Roland, K.P., 2001. Product mix and earnings volatility at commercial banks: Evidence from a degree of total leverage model. Journal of Financial Intermediation $10,54-84$.

Djankov, S., Jindra, J., Klapper, L.F., 2005. Corporate valuation and the resolution of bank insolvency in East Asia. Journal of Banking \& Finance 29, 2095-2118.

Djankov, S., La Porta, R., Lopez-de-Silanes, F., Shleifer, A., 2008. The law and economics of self-dealing. Journal of Financial Economics 88, 430-465. 
Eklund, J.E., Palmberg, J.K., Wiberg, D., 2009. Ownership structure, boardcomposition and investment performance. Working Paper Series in Economics and Institutions of Innovation.

Elron, E., 1997. Top management teams within multinational corporations: Effects of cultural heterogeneity. The Leadership Quarterly 8, 393-412.

Erhardt, N.L., Werbel, J.D., Shrader, C.B., 2003. Board of Director Diversity and Firm Financial Performance. Corporate Governance: An International Review 11, 102-111.

Erkens, D.H., Hung, M., Matos, P., 2012. Corporate governance in the 2007-2008 financial crisis: Evidence from financial institutions worldwide. Journal of Corporate Finance 18, 389-411.

Fahlenbrach, R., Stulz, R.M., 2011. Bank CEO incentives and the credit crisis. Journal of Financial Economics 99, 11-26.

Fama, E.F., 1980. Agency Problems and the Theory of the Firm. Journal of Political Economy 88, 288-307.

Fang, Y., Francis, B., Hasan, I., 2012. More than connectedness - Heterogeneity of CEO social network and firm value. Bank of Finland Research Discussion Paper 26.

Farrell, K.A., Hersch, P.L., 2005. Additions to corporate boards: the effect of gender. Journal of Corporate Finance 11, 85-106.

Ferreira, D., 2010. Board Diversity, in: Baker, H.K., Anderson, R. (Eds.), Corporate Governance: A Synthesis of Theory, Research, and Practice. John Wiley \& Sons, Inc., Hoboken, NJ, USA.

Gabrielsson, J., Huse, M., 2004. Context, behavior, and evolution: Challenges in research on boards and governance. International Studies of Management \& Organization 34, 11 36.

Grable, J., 2000. Financial Risk Tolerance and Additional Factors That Affect Risk Taking in Everyday Money Matters. Journal of Business and Psychology 14, 625-630.

Grable, J.E., McGill, S., Britt, S.L., 2009. Risk tolerance estimation bias : the age effect. Journal of Business \& Economics Research 7, 1-12.

Graham, J.R., Harvey, C.R., 2001. The theory and practice of corporate finance: evidence from the field. Journal of Financial Economics 60, 187-243.

Hagendorff, J., Keasey, K., 2012. The value of board diversity in banking: Evidence from the market for corporate control. European Journal of Finance 18, 41-58.

Hambrick, D.C., Cho, T.S., Chen, M.-J., 1996. The Influence of top management team heterogeneity on firms' competitive moves. Administrative Science Quarterly 41, 659-684. 
Hanazaki, M., Liu, Q., 2007. Corporate governance and investment in East Asian firmsempirical analysis of family-controlled firms. Journal of Asian Economics 18, 76-97.

Harjoto, M.A., Indrarini, L., Ya-wen, Y., 2014. Board diversity and corporate risk taking. SSRN Working Paper.

Harrison, D.A., Klein, K.J., 2007. What's the difference? diversity constructs as separation, variety, or disparity in organizations. Academy of Management Review 32, 1199-1228.

Harrison, D.A., Sin, H.-P., 2006. What is diversity and how should it be measured? , in: Konrad, A.M., Prasad, P., Pringle, J.K. (Eds.), Handbook of workplace diversity. SAGE Publications Ltd, London, pp. 192-218.

Hermalin, B.E., Weisbach, M.S., 2003. Boards of directors as an endogenously determined institution: A survey of the economic literature. Economic Policy Review, Federal Reserve Bank of New York, 7-26.

Hillman, A.J., Dalziel, T., 2003. Boards of directors and firm performance: Integrating agency and resource dependence perspectives. The Academy of Management Review 28, 383-396.

Jianakoplos, N.A., Bernasek, A., 1998. Are Women More Risk Averse? Economic Inquiry 36, 620-630.

Khanna, T., Yafeh, Y., 2007. Business groups in emerging markets: Paragons or parasites? Journal of Economic Literature 45, 331-372.

Kilduff, M., Angelmar, R., Mehra, A., 2000. Top Management-Team Diversity and Firm Performance: Examining the Role of Cognitions. Organization Science 11, 21-34.

Klein, A., 2002. Audit committee, board of director characteristics, and earnings management. Journal of Accounting and Economics 33, 375-400.

Knight, D., Pearce, C.L., Smith, K.G., Olian, J.D., Sims, H.P., Smith, K.A., Flood, P., 1999. Top management team diversity, group process, and strategic consensus. Strategic Management Journal 20, 445-465.

Laeven, L., 1999. Risk and efficiency in East Asian banks. Research Working Paper Series, The World Bank 2255.

Levine, R., 2004. The corporate governance of banks: A concise discussion of concepts and evidence. World Bank Policy Research Working Paper 3404.

Liang, Q., Xu, P., Jiraporn, P., 2013. Board characteristics and Chinese bank performance. Journal of Banking \& Finance 37, 2953-2968.

Lin, X., Zhang, Y., 2009. Bank ownership reform and bank performance in China. Journal of Banking \& Finance 33, 20-29. 
Macey, J.R., Maureen, O.H., 2003. The corporate governance of banks. Economic Policy Review 9.

Masulis, R.W., Wang, C., Xie, F., 2012. Globalizing the boardroom-The effects of foreign directors on corporate governance and firm performance. Journal of Accounting and Economics 53, 527-554.

Mateos de Cabo, R., Gimeno, R., Nieto, M., 2012. Gender Diversity on European Banks' Boards of Directors. Journal of Business Ethics 109, 145-162.

Mattis, M.C., 2000. Women corporate directors in the United States, in: Burke, R., Mattis, M. (Eds.), Women on corporate boards of directors. Springer Netherlands, pp. 43-56.

Maudos, J.n., Fernández de Guevara, J., 2004. Factors explaining the interest margin in the banking sectors of the European Union. Journal of Banking \& Finance 28, 2259-2281.

May, D.O., 1995. Do managerial motives influence firm risk reduction strategies? The Journal of Finance 50, 1291-1308.

Menteri Dalam Negeri, 1999. Peraturan Menteri Dalam Negeri No. 58 Tahun 1999 tentang Direksi dan Dewan Pengawas Bank Pembangunan Daerah (BPD), in: Menteri Dalam Negeri Republik Indonesia (Ed.), Jakarta, Indonesia.

Milliken, F.J., Martins, L.L., 1996. Searching for common threads: Understanding the multiple effects of diversity in organizational groups. The Academy of Management Review 21, 402-433.

Monks, R.A.G., Minow, N., 2011. Corporate Governance, 5th ed. Wiley.

Morgan, D.P., 2002. Rating Banks: Risk and Uncertainty in an Opaque Industry. The American Economic Review 92, 874-888.

Mueller, D.C., 2003. Public choice III, 3rd ed. Cambridge University Press.

Obata, S., 2003. Pyramid business groups in East Asia: Insurance or tunneling? CEI Working Paper Series 2002-13.

Pathan, S., 2009. Strong boards, CEO power and bank risk-taking. Journal of Banking \& Finance 33, 1340-1350.

Pathan, S., Faff, R., 2013. Does board structure in banks really affect their performance? Journal of Banking \& Finance 37, 1573-1589.

Pathan, S., Skully, M., Wickramanayake, J., 2008. Board size, independence and performance: An analysis of Thai banks. Asia-Pacific Financial Markets 14, 211-227.

Quack, S., Hancké, B., 1997. Women in decision making in finance. European Commission. 
Robinson, G., Dechant, K., 1997. Building a business case for diversity. The Academy of Management Executive 11, 21-31.

Rose, C., 2007. Does female board representation influence firm performance? The Danish Evidence. Corporate Governance: An International Review 15, 404-413.

Saito, R., Dutra, M.G.L., 2006. Board of directors of publicly-held companies in Brazil: Profile and implications for minority shareholders. Corporate Governance: An International Review 14, 98-106.

Schaffer, M.E., 2010. XTIVREG2: Stata module to perform extended IV/2SLS, GMM and AC/HAC, LIML and k-class regression for panel data models, Statistical Software Components. Boston College Department of Economics.

Shleifer, A., Vishny, R.W., 1997. A Survey of Corporate Governance. Journal of Finance $52,737-783$.

Shrader, C.B., Blackburn, V.B., Iles, P., 1997. Women In Management And Firm Financial Performance: An Exploratory Study. Journal of Managerial Issues 9, 355-372.

Simons, T., Pelled, L.H., Smith, K.A., 1999. Making use of difference diversity, debate, and decision comprehensiveness in top management teams. The Academy of Management Journal 42, 662-673.

Simpson, W.G.C., David A.; D'Souza, Frank, 2010. What do we know about women on boards? Journal of Applied Finance 20, 27-39.

Terjesen, S., Sealy, R., Singh, V., 2009. Women directors on corporate boards: A review and research agenda. Corporate Governance: An International Review 17, 320-337.

Terjesen, S., Singh, V., 2008. Female presence on corporate boards: A multi-country study of environmental context. Journal of Business Ethics 83, 55-63.

Timmerman, T.A., 2000. Racial diversity, qge Diversity, interdependence, and team performance. Small Group Research 31, 592-606.

Treichler, C.M., 1995. Diversity of Board Members and Organizational Performance: An integrative perspective. Corporate Governance: An International Review 3, 189-200.

Vafeas, N., 2003. Length of Board Tenure and Outside Director Independence. Journal of Business Finance \& Accounting 30, 1043-1064.

van der Walt, N., Ingley, C., 2003. Board Dynamics and the Influence of Professional Background, Gender and Ethnic Diversity of Directors. Corporate Governance: An International Review 11, 218-234. 
Watson, W.E., Johnson, L., Merritt, D., 1998. Team Orientation, Self-Orientation, and Diversity in Task Groups: Their Connection to Team Performance Over Time. Group \& Organization Management 23, 161-188.

Westphal, J.D., Milton, L.P., 2000. How Experience and Network Ties Affect the Influence of Demographic Minorities on Corporate Boards. Administrative Science Quarterly 45, 366-398.

Zhang, P., 2007. Top management team heterogeneity and firm performance: An empirical research on Chinese listed companies. Frontiers of Business Research in China 1, 123-134. Zhuang, J., David, E., Webb, D.C., Capulong, M.V., 2000. Corporate governance and finance in East Asia: a study of Indonesia, Republic of Korea, Malaysia, Philippines, and Thailand. Asian Development Bank, Manila, Philippines. 
Table 1 Descriptive statistics of performance, risk and diversity measures

\begin{tabular}{|c|c|c|c|c|c|}
\hline Variable & Obs & Mean & Std. Dev. & Min & Max \\
\hline \multicolumn{6}{|c|}{ Panel A. Performance and risk measures } \\
\hline ROA & 395 & 0.022 & 0.013 & 0.001 & 0.084 \\
\hline ROE & 394 & 0.185 & 0.115 & 0.000 & 0.612 \\
\hline adjusted ROA & 390 & 5.470 & 5.380 & 0.008 & 32.909 \\
\hline adjusted ROE & 390 & 5.135 & 5.274 & 0.007 & 29.573 \\
\hline SDROA & 405 & 0.010 & 0.017 & 0.001 & 0.168 \\
\hline SDROE & 405 & 0.090 & 0.179 & 0.005 & 2.213 \\
\hline Z-score & 406 & 9.924 & 10.875 & 0.161 & 70.626 \\
\hline Z-score 1 & 405 & 5.293 & 5.366 & -0.527 & 32.909 \\
\hline Z-score2 & 405 & 3.956 & 5.839 & 0.017 & 48.853 \\
\hline \multicolumn{6}{|c|}{ Panel B. Board characteristics } \\
\hline Female & 414 & 0.094 & 0.100 & 0 & 0.4 \\
\hline Ethnog diversity & 405 & 2.189 & 0.937 & 1 & 6.452 \\
\hline Professional diversity & 393 & 5.942 & 1.453 & 1.938 & 9.313 \\
\hline Education diversity & 395 & 1.220 & 0.386 & 0.556 & 4.010 \\
\hline \multicolumn{6}{|c|}{ Panel C. Control variables } \\
\hline Capital & 400 & 0.188 & 0.090 & 0.086 & 0.771 \\
\hline Loan & 416 & 0.567 & 0.178 & 0.010 & 0.932 \\
\hline Foreign bank & 418 & 0.227 & 0.420 & 0 & 1 \\
\hline Listed & 418 & 0.474 & 0.500 & 0 & 1 \\
\hline Business group & 418 & 0.589 & 0.493 & 0 & 1 \\
\hline Assets & 418 & 40100 & 72700 & 105.55 & 424000 \\
\hline Crisis & 418 & 0.091 & 0.288 & 0 & 1 \\
\hline
\end{tabular}

ROA is profits before taxes divided by average assets. ROE is profits before taxes divided by average equity. adjusted ROA (adjusted ROE) is the ratio of ROA (ROE) to its standard deviation calculated on last three year observation for the respective year. SDROA = the standard deviation of return on average assets based on three previous years data, $\mathrm{SDROE}=$ standard deviation of return on equity based on three previous years data, $\mathrm{Z}$-score $=(\mathrm{ROA}+$ Equity-to-Assets $) / \mathrm{SDROA}, \mathrm{Z}$-score1=ROA divided by SDROA, Z-score2= Equity-tototal assets divided by SDROA. Female is the percentage of female on the board. Ehtnog diversity is the average diversity index of ethnicity and nationality. Professional diversity is the average index of banking experience and tenure diversity. Education diversity is the average diversity index of education level and education type. Capital is the ratio of bank capital to its risk weighted assets. Loan is the ratio of total loans to total assets. Foreign bank is a dummy equals one if the bank is owned by foreign shareholders, zero otherwise. Listed equals one if the bank is publicly listed, zero otherwise. Assets is the bank's total assets (in billions Indonesia rupiah). Crisis denotes one for year 2008 and zero otherwise. 
Table 2 Board Diversity from 2001 to 2011

\begin{tabular}{ccccc}
\hline Year & Female div. & Ethnog div. & Professional div. & Education div. \\
\hline 2001 & 0.085 & 1.881 & 5.532 & 1.122 \\
2002 & 0.084 & 2.086 & 5.599 & 1.312 \\
2003 & 0.094 & 2.197 & 5.782 & 1.325 \\
2004 & 0.083 & 2.200 & 5.763 & 1.334 \\
2005 & 0.081 & 2.173 & 5.833 & 1.286 \\
2006 & 0.093 & 2.206 & 5.804 & 1.250 \\
2007 & 0.100 & 2.287 & 5.843 & 1.193 \\
2008 & 0.104 & 2.220 & 6.060 & 1.150 \\
2009 & 0.107 & 2.285 & 6.276 & 1.180 \\
2010 & 0.107 & 2.246 & 6.303 & 1.148 \\
2011 & 0.098 & 2.253 & 6.379 & 1.136 \\
\hline Total & 0.094 & 2.189 & 5.942 & 1.220 \\
\hline
\end{tabular}

Table 2 reports the mean values of diversity measures. Female is the percentage of female on the board. Ehtnog diversity is the average diversity index of ethnicity and nationality. Professional diversity is the average index of banking experience and tenure diversity. Education diversity is the average diversity index of education level and education type. 
Table 3 Correlation matrix

\begin{tabular}{|c|c|c|c|c|c|c|c|c|c|c|c|c|c|c|c|c|c|c|c|c|}
\hline No. & Variable & 1 & 2 & 3 & 4 & 5 & 6 & 7 & 8 & 9 & 10 & 11 & 12 & 13 & 14 & 15 & 16 & 17 & 18 & 19 \\
\hline 1 & ROA & 1 & & & & & & & & & & & & & & & & & & \\
\hline 2 & ROE & $0.6156^{*}$ & 1 & & & & & & & & & & & & & & & & & \\
\hline 3 & adjusted ROA & $0.2757^{*}$ & $0.2324 *$ & 1 & & & & & & & & & & & & & & & & \\
\hline 5 & SDROA & $0.3140^{*}$ & 0.0615 & $-0.6123^{*}$ & $-0.3951^{*}$ & 1 & & & & & & & & & & & & & & \\
\hline 6 & SDROE & $0.2275^{*}$ & $0.2717^{*}$ & $-0.4059^{*}$ & $-0.6085^{*}$ & $0.6492^{*}$ & 1 & & & & & & & & & & & & & \\
\hline 7 & Z-score & 0.0722 & 0.0764 & $0.6699^{*}$ & $0.6306^{*}$ & $-0.6896^{*}$ & $-0.7807^{*}$ & 1 & & & & & & & & & & & & \\
\hline 8 & Z-score1 & $0.0918^{*}$ & $0.3026^{*}$ & $0.7597^{*}$ & $0.5591^{*}$ & $-0.7561^{*}$ & $-0.5103^{*}$ & $0.8389^{*}$ & 1 & & & & & & & & & & & \\
\hline 9 & Z-score2 & -0.0809 & $-0.3433^{*}$ & $0.3373^{*}$ & $0.5161^{*}$ & $-0.4473^{*}$ & $-0.8946^{*}$ & $0.7756^{*}$ & $0.4341^{*}$ & 1 & & & & & & & & & & \\
\hline 10 & Female & $-0.1793^{*}$ & $-0.2200^{*}$ & -0.0147 & $-0.1057^{*}$ & $-0.1772 *$ & $-0.1034^{*}$ & 0.0247 & 0.0132 & 0.0267 & 1 & & & & & & & & & \\
\hline 11 & Ethnog diversity & -0.0821 & -0.0556 & $-0.1963^{*}$ & $-0.2013^{*}$ & $0.1164 *$ & $0.1878^{*}$ & $-0.1984^{*}$ & $-0.1570^{*}$ & $-0.1752 *$ & 0.005 & 1 & & & & & & & & \\
\hline 12 & Professional diversity & $-0.1705^{*}$ & $-0.1901^{*}$ & 0.0453 & $0.0972 *$ & $-0.1168^{*}$ & $-0.2193 *$ & $0.1171^{*}$ & 0.0714 & $0.2540^{*}$ & $0.2591^{*}$ & $-0.1387^{*}$ & 1 & & & & & & & \\
\hline 13 & Education diversity & -0.0138 & 0.0741 & $0.2004^{*}$ & $0.1442 *$ & $-0.1545^{*}$ & -0.0256 & 0.0757 & $0.1682 *$ & -0.0095 & -0.0064 & 0.0207 & 0.0117 & 1 & & & & & & \\
\hline 14 & Capital & $0.1798^{*}$ & $-0.2065^{*}$ & 0.0297 & -0.0292 & $0.2295^{*}$ & -0.0735 & $0.1680^{*}$ & -0.0479 & $0.2871^{*}$ & $-0.1506^{*}$ & -0.0755 & 0.0343 & $-0.1478^{*}$ & 1 & & & & & \\
\hline 15 & Loan & -0.002 & $-0.1577 *$ & $0.1442^{*}$ & $0.1585^{*}$ & $-0.1266^{*}$ & $-0.3013^{*}$ & $0.2381^{*}$ & $0.1471^{*}$ & $0.3577^{*}$ & 0.0705 & $-0.1272 *$ & $0.3296^{*}$ & 0.0592 & 0.0032 & 1 & & & & \\
\hline 16 & Foreign bank & $-0.1342 *$ & $-0.1475^{*}$ & -0.0567 & $-0.1175^{*}$ & 0.0474 & $0.1022^{*}$ & $-0.1418^{*}$ & $-0.0990^{*}$ & $-0.1123^{*}$ & $0.1985^{*}$ & $0.4192^{*}$ & 0.0824 & $0.0867^{*}$ & $-0.0870^{*}$ & $0.0976^{*}$ & 1 & & & \\
\hline 18 & Business group & $-0.1795^{*}$ & $-0.2727^{*}$ & 0.0103 & -0.0311 & $-0.1167^{*}$ & $-0.1706^{*}$ & $0.0928 *$ & 0.0263 & $0.2243^{*}$ & $0.1718^{*}$ & 0.0242 & $0.1670^{*}$ & $0.0942 *$ & 0.044 & 0.0174 & 0.0011 & $0.3649^{*}$ & 1 & \\
\hline 19 & Size & $0.1368^{*}$ & $0.3061^{*}$ & $0.0872^{*}$ & $0.1436^{*}$ & $-0.1220^{*}$ & 0.0131 & $0.0976^{*}$ & $0.1905^{*}$ & $-0.1050^{*}$ & -0.0771 & $0.2780^{*}$ & -0.0675 & -0.018 & $-0.0991^{*}$ & $-0.1789^{*}$ & 0.006 & $0.4011^{*}$ & $-0.2468^{*}$ & 1 \\
\hline 20 & Crisis & -0.0803 & -0.0801 & 0.0517 & $0.0962 *$ & $-0.1121^{*}$ & $-0.1426^{*}$ & 0.0686 & 0.0299 & $0.1162 *$ & 0.0303 & 0.0104 & 0.0265 & -0.0591 & -0.031 & $0.1237^{*}$ & 0.0271 & 0.0667 & 0.0108 & 0.0715 \\
\hline
\end{tabular}

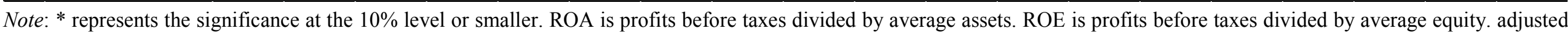

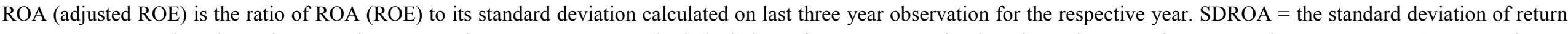

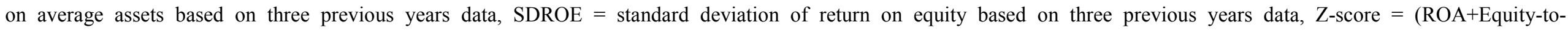

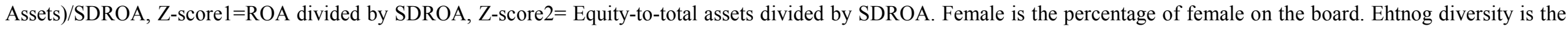

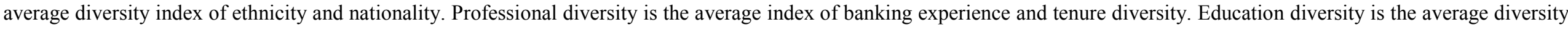

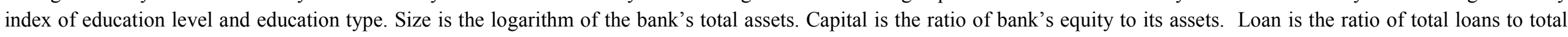

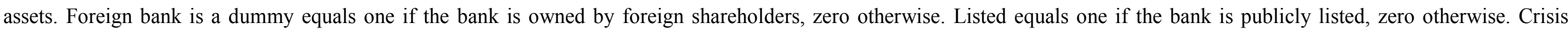
denotes one for year 2008 and zero otherwise. 
Table 4 The impact of board diversity on bank performance: IV/2SLS models

\begin{tabular}{|c|c|c|c|c|c|c|c|c|c|c|c|c|c|c|c|c|}
\hline \begin{tabular}{|c|} 
Dependent var. \\
Model
\end{tabular} & \multicolumn{4}{|c|}{ Return on assets (ROA) } & \multicolumn{4}{|c|}{ Return on Equity (ROE) } & \multicolumn{4}{|c|}{ adjusted ROA } & \multicolumn{4}{|c|}{ adjusted ROE } \\
\hline Female & -0.0206 & & & & $1.087^{* *}$ & & & & -17.41 & & & & -18.42 & & & \\
\hline & $(-0.74)$ & & & & $(1.96)$ & & & & $(-1.28)$ & & & & $(-1.62)$ & & & \\
\hline Ethnog diversity & & $-0.0265 * * *$ & & & & $-0.102 * *$ & & & & $-2.261 * *$ & & & & $-8.302 * *$ & & \\
\hline \multirow[t]{2}{*}{ Professional div. } & & & $0.00841^{* * *}$ & & & & $0.0274 *$ & & & & $5.155^{* * *}$ & & & & $2.200^{* *}$ & \\
\hline & & & $(3.22)$ & & & & $(1.66)$ & & & & $(3.05)$ & & & & $(2.53)$ & \\
\hline Education div & & & & $0.0339 * *$ & & & & $0.573 * *$ & & & & $7.520^{*}$ & & & & $8.397^{*}$ \\
\hline Size & $(-1.66)$ & $(-0.41)$ & $(-1.42)$ & $(0.93)$ & $(-1.40)$ & $(-1.06)$ & $(-1.45)$ & $(1.36)$ & $(2.10)$ & $(1.64)$ & $(0.99)$ & (3.33) & $(1.89)$ & $(1.78)$ & $(1.16)$ & $(2.39)$ \\
\hline \multirow[t]{2}{*}{ Capital } & $0.0222 * *$ & $0.0801 * * *$ & $0.0320^{* *}$ & $0.0521 * * *$ & -0.0642 & -0.0292 & $-0.199 * *$ & 0.0728 & $11.85^{* *}$ & $12.85^{* *}$ & $13.91^{* *}$ & $12.34^{*}$ & -5.441 & 6.243 & -2.486 & -0.458 \\
\hline & $(2.16)$ & $(2.95)$ & $(2.43)$ & $(3.20)$ & $(-0.83)$ & $(-0.27)$ & $(-2.08)$ & $(0.35)$ & (2.18) & $(2.42)$ & $(2.38)$ & $(1.96)$ & $(-1.18)$ & $(0.88)$ & $(-0.63)$ & $(-0.08)$ \\
\hline \multirow[t]{2}{*}{ Loan } & 0.000611 & 0.00219 & $-0.0211^{* *}$ & -0.00858 & $-0.272 * *$ & $-0.111^{*}$ & $-0.208^{* * *}$ & $-0.246^{* *}$ & $6.024^{*}$ & $5.259^{*}$ & -1.336 & 1.846 & 4.603 & 2.183 & -0.0824 & -0.171 \\
\hline & $(0.08)$ & $(0.20)$ & $(-2.16)$ & $(-0.93)$ & $(-2.47)$ & $(-1.79)$ & $(-3.18)$ & $(-1.97)$ & $(1.70)$ & $(1.80)$ & $(-0.29)$ & $(0.64)$ & $(1.46)$ & $(0.59)$ & $(-0.03)$ & $(-0.05)$ \\
\hline \multirow[t]{2}{*}{ Foreign bank } & -0.00350 & $0.0101^{*}$ & -0.000914 & 0.00807 & 0.0377 & 0.0330 & $-0.0385 * *$ & $0.164^{*}$ & $-5.496 * * *$ & -2.376 & $-4.630^{* *}$ & -1.929 & $-4.769 * * *$ & -0.220 & $-4.305 * * *$ & -2.187 \\
\hline & $(-1.41)$ & $(1.86)$ & $(-0.25)$ & $(1.27)$ & $(0.77)$ & $(1.11)$ & $(-1.99)$ & $(1.66)$ & $(-2.94)$ & $(-1.26)$ & $(-2.02)$ & $(-1.06)$ & $(-3.20)$ & $(-0.09)$ & $(-3.08)$ & $(-1.26)$ \\
\hline Crisis period & $(-2.26)$ & $(-2.03)$ & $(-1.38)$ & $(-0.10)$ & $(-1.74)$ & $(-2.13)$ & $(-1.12)$ & $(0.65)$ & $(0.63)$ & $(0.37)$ & $(0.22)$ & $(1.21)$ & (1.13) & $(0.45)$ & $(0.91)$ & $(1.75)$ \\
\hline No. obs. & 335 & 334 & 344 & 326 & 351 & 332 & 329 & 329 & 346 & 344 & 363 & 369 & 379 & 349 & 365 & 369 \\
\hline F-stat & $5.23 * * *$ & $2.33 * *$ & $3.84 * * *$ & $4.21^{* * *}$ & $2.267 * * *$ & $3.79 * * *$ & $5.17 * * *$ & $1.90^{*}$ & $2.63 * * *$ & $3.06 * * *$ & $2.82^{* * *}$ & $3.59 * * *$ & $4.69 * * *$ & $2.56^{* * *}$ & $4.62 * * *$ & $3.55^{* * *}$ \\
\hline Endog.test, Chi-sq: & 0.109 & $10.471^{* * *}$ & $6.676 * * *$ & $7.471^{* * *}$ & 0.093 & $5.076 * *$ & $3.560^{*}$ & $14.086^{* * *}$ & 2.558 & $4.237 * *$ & $8.578^{* * *}$ & 0.198 & $4.071^{* *}$ & $4.067 * *$ & $3.003^{*}$ & $5.314^{* *}$ \\
\hline
\end{tabular}

Note: The table above reports IV/2SLS regression using ROA, ROE, adjusted ROA and adjusted ROE as the dependent variables. Superscripts $*, * *, * *$ represent the significance at $\mathrm{p}<0.1, \mathrm{p}<0.05$, and $\mathrm{p}<0.01$ respectively. $\mathrm{t}$-statistics shown in parentheses are corrected for White heteroskedasticity. ROA is profits before taxes divided by average assets. ROE is profits before taxes divided by average equity. Adjusted ROA (adjusted ROE) is the ratio of ROA (ROE) to its standard deviation. Female is the percentage of female on the board. Ehtnog diversity is the average diversity index of ethnicity and nationality. Professional diversity is the average index of banking experience and tenure diversity. Education diversity is the average diversity index of education level and education type. Size is the logarithm of the bank's total assets. Capital is the ratio of bank's equity to its assets. Loan is the ratio of total loans to total assets. Foreign bank is a dummy equals one if the bank is owned by foreign shareholders, zero otherwise. Listed equals one if the bank is publicly listed, zero otherwise. Crisis denotes one for year 2008 and zero otherwise. See Appendix A for detailed descriptions. 
Table 5 The impact of board diversity on bank risk: IV/2SLS models

\begin{tabular}{|c|c|c|c|c|c|c|c|c|c|c|c|c|c|c|c|c|c|c|c|c|}
\hline \multirow{2}{*}{\begin{tabular}{|c|} 
Dependent var. \\
Model \\
\end{tabular}} & \multicolumn{4}{|c|}{ SDROA) } & \multicolumn{4}{|c|}{ SDROE } & \multicolumn{4}{|c|}{ Z-score } & \multicolumn{4}{|c|}{ Z-score1 } & \multicolumn{4}{|c|}{ Z-score2 } \\
\hline & (1) & (2) & (3) & (4) & (1) & $(2)$ & (3) & (4) & (1) & (2) & (3) & (4) & (5) & (6) & (7) & (8) & (9) & (10) & (11) & (12) \\
\hline \multirow[t]{2}{*}{ Female } & $-7.022 * * *$ & & & & $-1.458^{*}$ & & & & 1.020 & & & & 3.175 & & & & 1.079 & & & \\
\hline & $(-2.64)$ & & & & $(-1.74)$ & & & & $(0.38)$ & & & & $(1.07)$ & & & & $(0.41)$ & & & \\
\hline Ethnog diversity & & $1.043 * *$ & & & & $0.986^{* *}$ & & & & $-1.638 * * *$ & & & & $-2.398 * * *$ & & & & $-1.135^{* *}$ & & \\
\hline \multirow[t]{2}{*}{ Professional div. } & & & $-0.399 * * *$ & & & & $-0.435 * * *$ & & & & $0.854 * * *$ & & & & $0.873^{* * *}$ & & & & $0.496 * * *$ & \\
\hline & & & $(-2.82)$ & & & & $(-2.77)$ & & & & $(4.07)$ & & & & $(4.26)$ & & & & $(2.73)$ & \\
\hline \multirow[t]{2}{*}{ Education div } & & & & $2.055^{*}$ & & & & $2.251^{*}$ & & & & -0.199 & & & & 1.450 & & & & $-3.574 *$ \\
\hline & & & & $(1.76)$ & & & & $(1.87)$ & & & & $(-0.23)$ & & & & $(1.27)$ & & & & $(-1.91)$ \\
\hline \multirow[t]{2}{*}{ Size } & $-0.293 * * *$ & $-0.416^{* * *}$ & $-0.342 * * *$ & -0.162 & $-0.256^{* * *}$ & $-0.330 * *$ & $-0.303 * * *$ & -0.100 & $0.216^{* * *}$ & $0.343^{* *}$ & $0.314 * *$ & $0.232 *$ & $0.241 * *$ & $0.361^{*}$ & $0.260 *$ & $0.374 * *$ & $0.282 * * *$ & $0.352 * *$ & $0.315^{* * *}$ & -0.0291 \\
\hline & $(-2.87)$ & $(-3.51)$ & $(-3.50)$ & $(-1.30)$ & $(-2.71)$ & $(-2.38)$ & $(-2.97)$ & $(-0.62)$ & $(2.61)$ & $(2.15)$ & $(2.26)$ & $(1.89)$ & $(2.50)$ & $(1.80)$ & $(1.85)$ & $(2.35)$ & $(2.98)$ & $(2.21)$ & $(2.74)$ & $(-0.13)$ \\
\hline \multirow[t]{2}{*}{ Capital } & -0.556 & $-2.872^{*}$ & -0.958 & 0.513 & -0.159 & -2.070 & -0.836 & 0.521 & 0.831 & $4.248^{* *}$ & 1.599 & 0.995 & 1.359 & $6.694^{* * *}$ & $2.544^{*}$ & $2.901 *$ & $2.640^{* *}$ & $4.637 * * *$ & $2.815^{* *}$ & 0.671 \\
\hline & $(-0.52)$ & $(-1.70)$ & $(-0.85)$ & $(0.45)$ & $(-0.17)$ & $(-1.44)$ & $(-0.82)$ & $(0.48)$ & $(0.95)$ & $(2.40)$ & $(1.35)$ & $(1.03)$ & $(1.28)$ & $(2.81)$ & $(1.92)$ & $(1.89)$ & $(2.36)$ & $(2.82)$ & $(2.45)$ & $(0.49)$ \\
\hline \multirow[t]{2}{*}{ Loan } & 0.170 & -0.760 & -0.215 & $-1.223 *$ & $-1.139 * *$ & $-1.498 * * *$ & -0.716 & $-1.714 * *$ & 0.738 & 1.015 & -0.441 & $0.904 *$ & 0.0331 & 1.200 & -0.677 & 0.00249 & $1.584 * *$ & $1.923^{* * *}$ & 0.985 & $2.355^{* *}$ \\
\hline & $(0.25)$ & $(-1.35)$ & $(-0.37)$ & $(-1.87)$ & $(-2.16)$ & $(-2.66)$ & $(-1.07)$ & $(-2.42)$ & $(1.19)$ & $(1.50)$ & $(-0.55)$ & $(1.65)$ & $(0.05)$ & $(1.33)$ & $(-0.84)$ & $(0.00)$ & $(2.10)$ & $(2.99)$ & $(1.33)$ & $(2.49)$ \\
\hline \multirow[t]{2}{*}{ Foreign bank } & -0.00450 & -0.125 & $0.500^{* *}$ & $1.068^{* *}$ & $0.470^{* *}$ & 0.0488 & $0.668 * * *$ & $1.257 * * *$ & $-0.488^{*}$ & 0.171 & $-0.876^{* *}$ & $-0.638^{*}$ & -0.534 & 0.437 & $-0.964 * * *$ & -0.199 & -0.361 & 0.0985 & $-0.608 * * *$ & $-1.590^{* *}$ \\
\hline & $(-0.01)$ & $(-0.40)$ & $(1.97)$ & $(2.27)$ & $(2.43)$ & $(0.17)$ & $(2.81)$ & $(2.63)$ & $(-1.89)$ & $(0.49)$ & $(-2.47)$ & $(-1.70)$ & $(-1.64)$ & $(0.92)$ & $(-2.63)$ & $(-0.39)$ & $(-1.43)$ & $(0.31)$ & $(-2.64)$ & $(-2.25)$ \\
\hline \multirow[t]{2}{*}{ Listed } & 0.243 & -0.0343 & $0.424^{*}$ & 0.177 & $-0.467 * * *$ & $-0.741 * * *$ & -0.296 & $-0.559 * * *$ & 0.168 & $0.715^{* *}$ & -0.155 & 0.189 & -0.108 & 0.623 & -0.470 & -0.151 & $0.608 * * *$ & $0.989 * * *$ & $0.478 * *$ & $0.842 * * *$ \\
\hline & $(1.08)$ & $(-0.13)$ & $(1.86)$ & $(0.73)$ & $(-2.74)$ & $(-2.67)$ & $(-1.59)$ & $(-2.87)$ & $(1.02)$ & $(2.39)$ & $(-0.59)$ & $(1.09)$ & $(-0.49)$ & $(1.48)$ & $(-1.45)$ & $(-0.59)$ & $(3.20)$ & $(3.25)$ & $(2.28)$ & $(3.52)$ \\
\hline Group business & -0.555 & -0.389 & $0.890 * * *$ & $1.082 * * *$ & -0.522 & -0.537 & $0.698 * * *$ & $0.870^{* *}$ & 0.267 & $1.351^{* * *}$ & $-0.915 * * *$ & 0.0640 & 0.544 & $1.864 * * *$ & $-0.924 * * *$ & 0.642 & 0.302 & $0.972 * *$ & $-0.454 *$ & -0.963 \\
\hline \multirow[t]{2}{*}{ Crisis period } & -0.158 & -0.0829 & -0.123 & -0.0418 & $-0.217^{* *}$ & -0.168 & -0.181 & -0.0627 & 0.101 & 0.0239 & 0.0937 & 0.0885 & -0.0302 & -0.185 & -0.0409 & 0.0758 & 0.182 & 0.147 & 0.166 & -0.0388 \\
\hline & $(-1.25)$ & $(-0.61)$ & $(-0.91)$ & $(-0.29)$ & $(-2.15)$ & $(-1.38)$ & $(-1.46)$ & $(-0.43)$ & $(0.90)$ & $(0.15)$ & $(0.50)$ & $(0.70)$ & $(-0.21)$ & $(-0.84)$ & $(-0.18)$ & $(0.47)$ & (1.58) & $(1.06)$ & $(1.19)$ & $(-0.20)$ \\
\hline No. obs. & 357 & 341 & 337 & 348 & 356 & 353 & 334 & 336 & 354 & 352 & 345 & 338 & 344 & 343 & 336 & 328 & 343 & 352 & 334 & 336 \\
\hline F-stat & $2.551 * * *$ & $3.010 * * *$ & $3.737 * * *$ & $2.933 * * *$ & $7.704 * * *$ & $6.799^{* * *}$ & $7.035 * * *$ & $6.1020 * * *$ & $5.141 * * *$ & $3.646 * * *$ & $4.515^{* * *}$ & $5.395 * * *$ & $2.242 * * *$ & $2.645^{* * *}$ & $3.707 * * *$ & $1.629 * * *$ & $8.605^{* * *}$ & $9.307 * * *$ & $11.61 * * *$ & $5.696 * * *$ \\
\hline Endog. test & 2.532 & $7.500 * * *$ & $9.587 * * *$ & $3.662 *$ & 0.826 & 0.097 & $4.136^{* *}$ & $4.267^{* *}$ & 0.9325 & $6.462^{* *}$ & $14.391 * * *$ & 0.001 & 1.005 & $18.081^{* * *}$ & $24.243 * * *$ & 2.471 & 1.634 & 0.662 & $4.285^{* *}$ & $6.400 * *$ \\
\hline
\end{tabular}

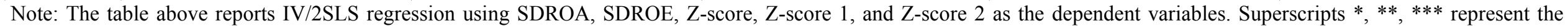

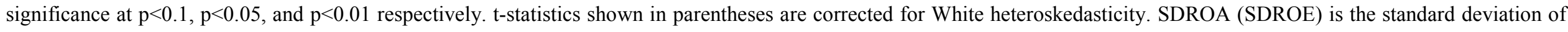

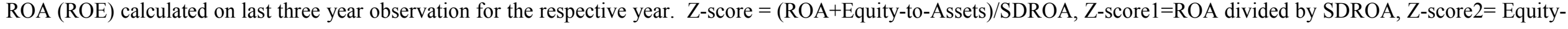

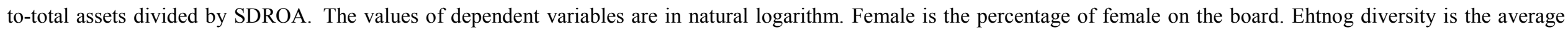

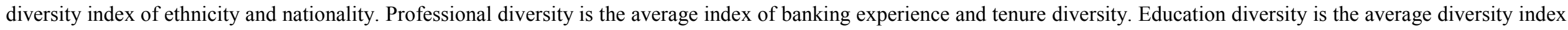

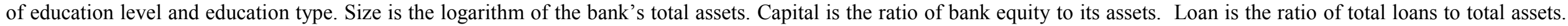

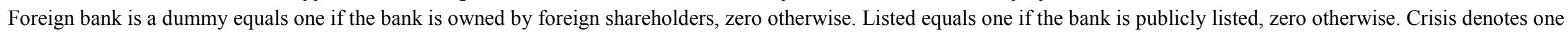
for year 2008 and zero otherwise. See Appendix A for detailed descriptions. 
Table 6 The impact of board diversity on bank performance: IV/2SLS models on individual diversity dimensions

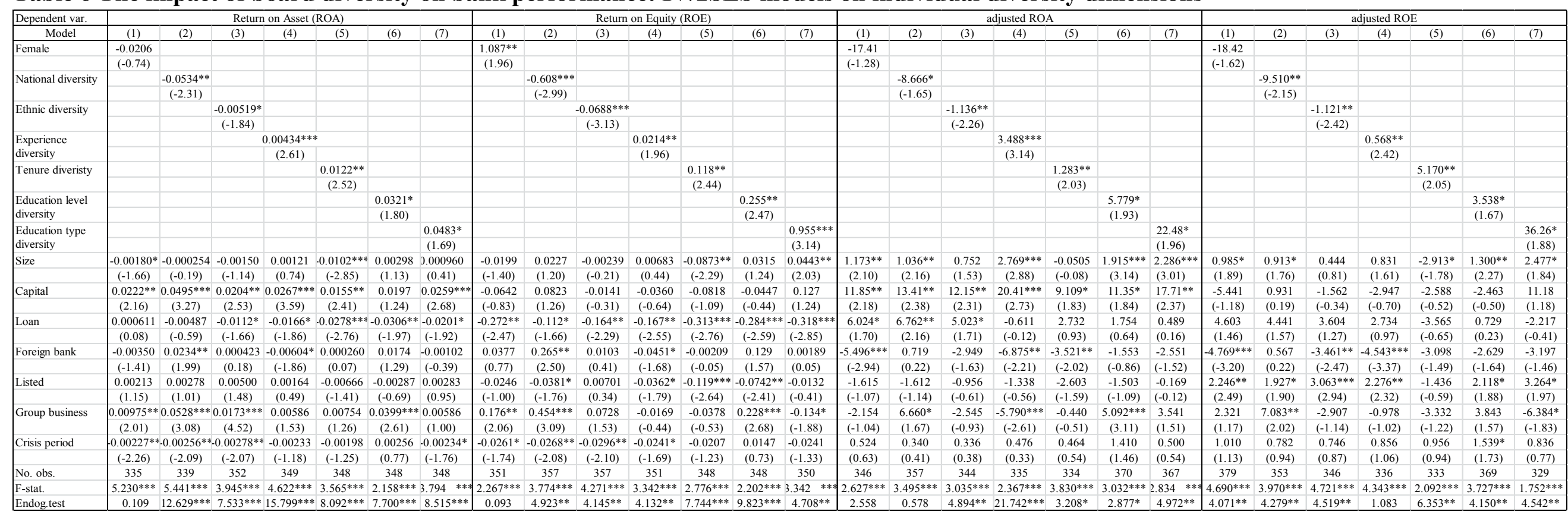

Note: The table above reports IV/2SLS regression using ROA, ROE, adjusted ROA and adjusted ROE as the dependent variables. Superscripts *, **, *** represent the significance at $\mathrm{p}<0.1, \mathrm{p}<0.05$, and $\mathrm{p}<0.01$ respectively. t-statistics shown in parentheses are corrected for White heteroskedasticity. ROA is profits before taxes divided by average assets. ROE is profits before taxes divided by average equity. Adjusted ROA (adjusted ROE) is the ratio of ROA (ROE) to its standard deviation calculated on last three year observation for the respective year. Female is the percentage of female on the board. National and ethnicity diversities are the diversity measures (indices) based on nationality and ethnicity respectively. Experience diversity is the diversity index calculated as standard deviation of the years of banking experience. Tenure diversity is the standard deviation of tenure periods of board members. Education level diversity is the diversity based on highest education level, whereas education type diversity is the ratio of directors with education other than economics, finance, accounting, and business. Size is the logarithm of the bank's total assets. Capital is the ratio of bank's equity to its assets. Loan is the ratio of total loans to total assets. Foreign bank is a dummy equals one if the bank is owned by foreign shareholders, zero otherwise. Listed equals one if the bank is publicly listed, zero otherwise. Crisis denotes one for year 2008 and zero otherwise. See Appendix A for detailed descriptions. 
Table 7 The impact of board diversity on bank risk: IV/2SLS models on individual diversity dimensions

\begin{tabular}{|c|c|c|c|c|c|c|c|c|c|c|c|c|c|c|c|c|c|c|c|c|c|c|c|c|c|c|c|c|c|c|c|c|c|c|c|}
\hline \multirow{2}{*}{\begin{tabular}{|l|} 
Dependent var. \\
Model \\
\end{tabular}} & \multicolumn{7}{|c|}{ SDROA } & \multicolumn{7}{|c|}{ SDROE } & \multicolumn{7}{|c|}{ Z-score } & \multicolumn{7}{|c|}{ Z-score 1} & \multicolumn{7}{|c|}{ Z-score 2} \\
\hline & (1) & (2) & (3) & (4) & (5) & (6) & (7) & (1) & (2) & (3) & (4) & (5) & (6) & (7) & (1) & (2) & (3) & (4) & (5) & (6) & (7) & (1) & (2) & (3) & (4) & (5) & (6) & (7) & (1) & (2) & (3) & (4) & (5) & (6) & (7) \\
\hline & $7.022^{* * *}$ & & & & & & & $-1.458^{*}$ & & & & & & & $1.942^{* *}$ & & & & & & & $1.764^{*}$ & & & & & & & $1.458^{*}$ & & & & & & \\
\hline & $(-2.64)$ & & & & & & & $(-1.74)$ & & & & & & & $(2.21)$ & & & & & & & (1.73) & & & & & & & $(1.68)$ & & & & & & \\
\hline National diversity & & $11.05^{* * *}$ & & & & & & & $4.274^{* *}$ & & & & & & & $-11.77^{* * *}$ & & & & & & & $-12.82^{* * *}$ & & & & & & & $-8.406^{* * *}$ & & & & & \\
\hline & & $(3.29)$ & & & & & & & $(2.40)$ & & & & & & & $(-3.53)$ & & & & & & & $(-3.88)$ & & & & & & & $(-3.02)$ & & & & & \\
\hline Ethnic diversity & & & $0.660^{* *}$ & & & & & & & $0.190^{* *}$ & & & & & & & $-0.213^{* *}$ & & & & & & & $-0.278^{* *}$ & & & & & & & $-0.198^{*}$ & & & & \\
\hline & & & $(2.41)$ & & & & & & & $(2.02)$ & & & & & & & $(-2.19)$ & & & & & & & $(-2.15)$ & & & & & & & $(-1.75)$ & & & & \\
\hline Experience diversity & & & & $-0.327^{* * *}$ & & & & & & & $-0.0974^{* * *}$ & & & & & & & $0.484^{* * *}$ & & & & & & & $0.685^{* * *}$ & & & & & & & $0.398^{* * *}$ & & & \\
\hline & & & & $(-2.74)$ & & & & & & & $(-2.63)$ & & & & & & & $(3.49)$ & & & & & & & $(3.61)$ & & & & & & & (2.86) & & & \\
\hline Tenure diversity & & & & & $-1.269^{* *}$ & & & & & & & $-0.763^{* * *}$ & & & & & & & $0.251^{1 * * *}$ & & & & & & & $0.238^{* *}$ & & & & & & & $1.854 * * *$ & & \\
\hline & & & & & $(-2.09)$ & & & & & & & $(-3.16)$ & & & & & & & $(2.66)$ & & & & & & & $(2.14)$ & & & & & & & $(4.18)$ & & \\
\hline Education level & & & & & & $0.301^{*}$ & & & & & & & $0.470^{* * *}$ & & & & & & & $-0.323^{* *}$ & & & & & & & $1.794^{* *}$ & & & & & & & $-2.494^{*}$ & \\
\hline & & & & & & $(1.82)$ & & & & & & & $(3.27)$ & & & & & & & $(-2.11)$ & & & & & & & $(2.30)$ & & & & & & & $(-1.83)$ & \\
\hline \begin{tabular}{|l} 
Education type \\
diversity
\end{tabular} & & & & & & & $\begin{array}{l}7.869 * * \\
(2.00)\end{array}$ & & & & & & & $\begin{array}{l}7.869^{* *} \\
(2.00)\end{array}$ & & & & & & & $\begin{array}{l}3.953^{*} \\
(1.82)\end{array}$ & & & & & & & $\begin{array}{l}5.312^{* *} \\
(225)\end{array}$ & & & & & & & $\begin{array}{l}-4.597 * \\
(-205)\end{array}$ \\
\hline Size & $-0.293 * * *$ & $-0.983 * *$ & $-0.368^{* * *}$ & $-0.557 * *$ & 0.451 & $-0.304^{* * *}$ & $\begin{array}{c}-0.00231 \\
-0.0231\end{array}$ & $-0.256^{* * *}$ & $-0.489 * *$ & $-0.278^{* * * *}$ & $*-0.350^{* * *}$ & 0.209 & $-0.225 * *$ & $=-0.00231$ & $0.209^{* *}$ & $0.988^{* * *}$ & $0.243^{* *}$ & $0.622^{* * * *}$ & 0.0812 & $0.186^{* *}$ & $\begin{array}{l}(1.1 .52) \\
0.518^{* * *}\end{array}$ & $0.203^{*}$ & $0.855^{* * *}$ & $0.225^{*}$ & $0.667^{7 * * *}$ & 0.0572 & $0.555^{* * *}$ & $=0.022^{* * * *}$ & $0.248^{* *}$ & $0.777^{* * * *}$ & $0.273^{* *}$ & $0.577^{* * *}$ & $*-0.886^{* * *}$ & * -0.0618 & $\begin{array}{l}(-2.00) \\
0.0886\end{array}$ \\
\hline & $(-2.87)$ & $(-3.56)$ & $(-2.85)$ & $(-4.63)$ & (1.07) & $(-3.22)$ & $(-0.01)$ & $(-2.71)$ & $(-3.34)$ & $(-2.66)$ & $(-3.74)$ & $(1.12)$ & $(-2.21)$ & $(-0.01)$ & $(2.39)$ & $(3.33)$ & (2.46) & $(4.08)$ & $(0.69)$ & $(2.00)$ & $(3.41)$ & (1.94) & $(3.09)$ & $(1.91)$ & $(3.43)$ & $(0.40)$ & $(2.98)$ & (3.37) & (2.36) & (3.26) & $(2.28)$ & $(3.90)$ & $(-2.70)$ & $(-0.23)$ & $(0.57)$ \\
\hline Capital & -0.556 & $-7.625 * *$ & $-2.802^{*}$ & -1.027 & -0.581 & -0.289 & $3.014^{*}$ & -0.159 & $-2.672^{*}$ & -0.674 & -0.335 & -0.570 & 0.0790 & $3.014^{*}$ & 0.892 & $8.889^{* * * *}$ & 1.452 & 1.623 & 0.839 & 0.632 & $3.096^{* *}$ & 0.948 & $10.47^{* * *}$ & 1.813 & $2.934^{*}$ & 0.915 & 2.073 & $3.493^{* *}$ & $1.997^{*}$ & $7.644^{* * * *}$ & $2.545^{* *}$ & $2.787^{* *}$ & 2.496 & 0.737 & 0.436 \\
\hline & $(-0.52)$ & $(-2.53)$ & $(-1.77)$ & $(-0.84)$ & $(-0.39)$ & $(-0.28)$ & $(1.72)$ & $(-0.17)$ & $(-1.66)$ & $(-0.71)$ & $(-0.35)$ & $(-0.62)$ & $(0.08)$ & $(1.72)$ & $(1.01)$ & $(2.84)$ & $(1.55)$ & (1.24) & $(0.99)$ & $(0.73)$ & $(2.17)$ & $(0.86)$ & $(3.34)$ & (1.44) & $(1.84)$ & $(0.81)$ & $(1.27)$ & $(2.11)$ & $(1.85)$ & $(2.85)$ & $(2.41)$ & $(2.03)$ & $(1.64)$ & $(0.46)$ & $(0.31)$ \\
\hline Loan & 0.170 & $-2.413^{*}$ & -0.764 & -0.281 & 1.278 & -0.803 & $-2.166^{* *}$ & $-1.139 * *$ & $-2.102^{* * *}$ & $1.396^{* * *}$ & $*-1.259 * *$ & -0.302 & $-1.490^{* * *}$ & $*-2.166^{* *}$ & 0.800 & $2.554^{* *}$ & $1.109^{* *}$ & 0.131 & 0.641 & $1.209 * *$ & 0.537 & 0.726 & $2.634^{* *}$ & $1.173^{*}$ & -0.321 & 0.686 & 0.471 & 0.373 & $1.537^{* *}$ & $2.773^{* * *}$ & $1.789^{* * *}$ & 1.118 & -1.055 & $2.614^{* *}$ & $2.511^{* * *}$ \\
\hline & $(0.25)$ & $(-1.92)$ & $(-1.25)$ & $(-0.45)$ & $(1.00)$ & $(-1.60)$ & $(-2.03)$ & \begin{tabular}{|l|}
$(-2.16)$ \\
\end{tabular} & $(-3.04)$ & $(-2.82)$ & $(-2.45)$ & $(-0.40)$ & $(-2.84)$ & $(-2.03)$ & (1.63) & $(2.07)$ & $(2.23)$ & $(0.17)$ & (1.28) & $(2.42)$ & $(0.80)$ & $(1.10)$ & $(2.01)$ & $(1.67)$ & $(-0.32)$ & $(0.98)$ & $(0.50)$ & $(0.44)$ & $(2.51)$ & $(2.73)$ & (3.13) & $(1.39)$ & $(-0.85)$ & (2.38) & $(3.10)$ \\
\hline Foreign bank & -0.00450 & $-4.717 * * *$ & 0.0782 & $0.683^{* *}$ & 0.182 & $0.609 * *$ & $0.694^{*}$ & $0.470^{* * *}$ & $-1.624^{*}$ & $0.417^{* * *}$ & $0.627^{* * *}$ & 0.396 & $0.832^{* * *}$ & $0.694^{*}$ & $-0.402^{*}$ & $4.785^{* * *}$ & -0.364 & $-0.991^{* * *}$ & $-0.460^{*}$ & $-0.680^{* *}$ & $-0.419^{*}$ & -0.284 & $5.251^{* * * *}$ & -0.190 & $-1.186^{* *}$ & -0.329 & 0.236 & -0.188 & $-0.356^{*}$ & $3.512^{* *}$ & -0.299 & $-0.780^{* * *}$ & * $\quad-0.0971$ & $-1.986^{* *}$ & $-0.614^{* *}$ \\
\hline & $(-0.01)$ & $(-2.81)$ & $(0.29)$ & $(2.31)$ & $(0.48)$ & (2.41) & (1.70) & (2.43) & $(-1.73)$ & $(2.05)$ & $(3.38)$ & $(1.51)$ & $(3.60)$ & $(1.70)$ & $(-1.72)$ & $(2.92)$ & $(-1.46)$ & $(-2.75)$ & $(-1.96)$ & $(-2.51)$ & $(-1.72)$ & $(-0.73)$ & (3.11) & $(-0.48)$ & $(-2.46)$ & $(-0.85)$ & $(0.44)$ & $(-0.47)$ & $(-1.75)$ & $(2.57)$ & $(-1.38)$ & $(-2.78)$ & $(-0.21)$ & $(-2.07)$ & $(-2.00)$ \\
\hline Listed & 0.243 & 0.291 & -0.190 & 0.235 & $1.166^{*}$ & 0.190 & 0.496 & $-0.467^{* * * *}$ & $-0.409 * *$ & $-0.565^{* * *}$ & $*-0.435 * *$ & 0.115 & $-0.503^{* * *}$ & * 0.496 & 0.207 & 0.0403 & $0.309^{*}$ & 0.156 & -0.00321 & 0.227 & $0.555^{* *}$ & -0.147 & -0.0572 & -0.00162 & -0.0890 & -0.333 & -0.146 & 0.197 & $0.671^{* * * *}$ & $0.534^{* *}$ & $0.771^{* * *}$ & $0.621^{* *}$ & -0.717 & $1.011^{* * *}$ & * $0.490^{* *}$ \\
\hline & (1.08) & $(0.83)$ & $(-0.62)$ & $(0.84)$ & (1.94) & $(0.83)$ & (1.46) & $(-2.74)$ & $(-2.05)$ & $(-3.22)$ & $(-2.53)$ & $(0.44)$ & $(-2.98)$ & (1.46) & (1.28) & $(0.12)$ & $(1.79)$ & $(0.54)$ & $(-0.02)$ & (1.37) & $(2.27)$ & $(-0.66)$ & $(-0.16)$ & $(-0.01)$ & $(-0.22)$ & $(-1.36)$ & $(-0.49)$ & $(0.68)$ & $(3.60)$ & $(2.00)$ & $(4.15)$ & $(2.39)$ & $(-1.44)$ & (2.98) & $(2.05)$ \\
\hline Group business & -0.555 & $-7.373 * * *$ & -0.115 & $1.026^{* * * *}$ & $1.073^{*}$ & $0.658^{* * * *}$ & -0.724 & -0.522 & $-3.618^{* * *}$ & 0.0383 & -0.280 & $0.588^{*}$ & $0.569^{* * *}$ & -0.724 & $0.420^{* * *}$ & $8.380^{* * * *}$ & -0.225 & $-0.801^{* * *}$ & 0.171 & 0.0998 & $1.520^{* * *}$ & 0.278 & $9.233^{* * *}$ & -0.544 & $-1.142^{* * *}$ & 0.0307 & $2.518^{* * *}$ & $2.056^{* *}$ & $0.808^{* *}$ & $6.100^{* * *}$ & 0.228 & $-0.617 * *$ & -0.835 & $-1.861^{*}$ & $0.821^{* *}$ \\
\hline & $(-1.37)$ & $(-3.07)$ & $(-0.35)$ & $(4.19)$ & $(1.72)$ & $(3.66)$ & $(-1.07)$ & $(-1.33)$ & $(-2.58)$ & $(0.13)$ & $(-0.56)$ & $(1.90)$ & $(3.29)$ & $(-1.07)$ & \begin{tabular}{|l|}
$(2.69)$ \\
\end{tabular} & (3.54) & $(-0.55)$ & $(-2.82)$ & $(0.79)$ & $(0.38)$ & $(2.66)$ & $(1.57)$ & $(3.87)$ & $(-0.92)$ & $(-2.97)$ & $(0.14)$ & $(3.41)$ & $(2.17)$ & $(2.09)$ & $(3.02)$ & $(0.64)$ & $(-2.07)$ & $(-1.16)$ & $(-1.70)$ & $(2.00)$ \\
\hline Crisis period & -0.158 & -0.0958 & -0.120 & -0.164 & -0.217 & -0.131 & -0.187 & $-0.217^{* *}$ & -0.180 & $-0.197^{*}$ & $-0.208 * *$ & $-0.231^{*}$ & -0.158 & -0.187 & 0.0987 & 0.0255 & 0.0746 & 0.0792 & 0.100 & 0.0464 & 0.120 & -0.0430 & -0.124 & -0.0764 & -0.0738 & -0.0485 & 0.235 & -0.0450 & $0.203^{*}$ & 0.135 & 0.181 & 0.190 & 0.252 & -0.142 & $0.218^{*}$ \\
\hline & $(-1.25)$ & $(-0.48)$ & $(-0.84)$ & $(-1.05)$ & $(-1.20)$ & $(-1.13)$ & $(-1.07)$ & $(-2.15)$ & $(-1.56)$ & $(-1.86)$ & $(-2.02)$ & $(-1.85)$ & $(-1.54)$ & $(-1.07)$ & $(0.87)$ & $(0.13)$ & $(0.62)$ & $(0.41)$ & (0.86) & $(0.39)$ & $(0.88)$ & $(-0.30)$ & $(-0.55)$ & $(-0.49)$ & $(-0.26)$ & $(-0.33)$ & (1.12) & $(-0.27)$ & (1.81) & $(0.82)$ & (1.54) & (1.15) & (1.20) & $(-0.53)$ & $(1.71)$ \\
\hline No. obs. & 357 & 363 & 351 & 344 & 345 & 343 & 350 & 356 & 352 & 352 & 345 & 345 & 343 & 350 & 355 & 360 & 351 & 346 & 341 & 344 & 373 & 345 & 346 & 343 & 337 & 334 & 367 & 364 & 356 & 354 & 352 & 346 & 345 & 348 & 347 \\
\hline F-stat. & $2.551^{* * *}$ & $2.726^{6 * *}$ & $3.873^{* * *}$ & $2.078^{* * *}$ & $4.134 * *$ & $2.338 * * *$ & $8.025^{* * *}$ & $7.704 * * *$ & $15.11^{* * *}$ & $8.157^{* * *}$ & * $6.260^{* * *}$ & $9.235^{* * *} 2$ & $2.338 * * *$ & * $9.526^{* * *}$ & $2.892^{* * *}$ & $5.217^{7 * * *}$ & $4.673^{* * *}$ & $6.240^{* * * *}$ & $4.884 * * *$ & $5.910 * * *$ & * $5.564^{* * *}$ & $2.763^{* * *}$ & * $2.699^{* * *}$ & $2.84^{7 * * *}$ & $3.383^{* * *}$ & $3.564^{* * *}$ & $3.787 * * *$ & * $9.091^{* * *}$ & $5.700^{* * *}$ & $20.33^{* * *}$ & $6.789 * * *$ & $4.559^{* * * *}$ & $4.390^{* * *}$ & $8.259 * * *$ & $* * *$ \\
\hline Endog. test & 2.532 & $11.481^{* * * 4}$ & $8.955 * * *$ & $11.636^{* * *}$ & $10.261^{* * *}$ & 0.810 & $17.195 * * *$ & $\begin{array}{l}0.826 \\
\end{array}$ & $7.024 * * *$ & $2.717^{*}$ & 1.435 & $8.552^{* * *}$ & 0.811 & $4.446^{* *}$ & $4.156^{* *} 1$ & $18.463^{* * *}$ & * $6.096^{* *}$ & $12.513^{* * *}$ & $4.353^{* *}$ & 0.743 & 0.951 & 1.346 & $27.666^{* * *}$ & $5.030 * 2$ & $24.071^{* * *}$ & $3.762^{* *}$ & $7.154^{* * *}$ & $3.470^{*}$ & 0.2837 & $9.477^{* * *}$ & $3.088^{*}$ & $8.449 * * \ldots$ & $* 22.830^{* * *}$ & * $6.83^{* * *}$ & 2.304 \\
\hline
\end{tabular}

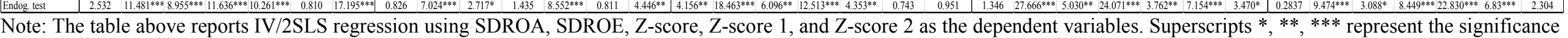

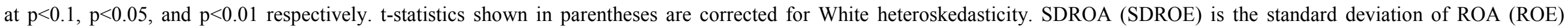

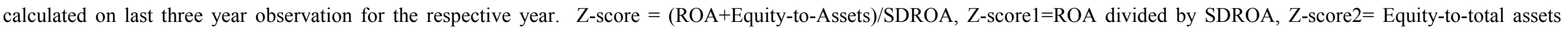

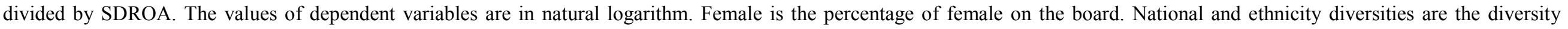

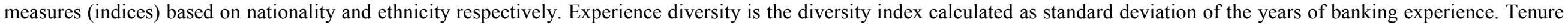

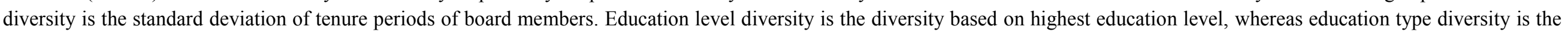

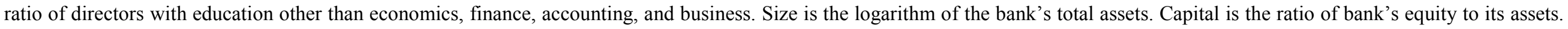

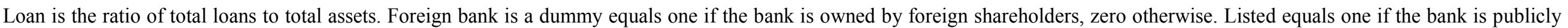
listed, zero otherwise. Crisis denotes one for year 2008 and zero otherwise. See Appendix A for detailed descriptions. 
Table 8 The impact of board diversity on bank performance: Alternative performance measures

\begin{tabular}{|c|c|c|c|c|c|c|c|c|}
\hline \multirow{2}{*}{\begin{tabular}{|r|} 
Dependent var. \\
Model
\end{tabular}} & \multicolumn{4}{|c|}{ NIM } & \multicolumn{4}{|c|}{ OEOI } \\
\hline & (1) & (2) & (3) & (4) & $(1)$ & (2) & (3) & (4) \\
\hline \multirow[t]{2}{*}{ Female } & $0.0281 *$ & & & & $-1.088^{* *}$ & & & \\
\hline & $(1.77)$ & & & & $(-2.29)$ & & & \\
\hline \multirow[t]{2}{*}{ Ethnog diversity } & & 0.00371 & & & & $0.176^{* * *}$ & & \\
\hline & & $(1.11)$ & & & & $(3.06)$ & & \\
\hline \multirow[t]{2}{*}{ Professional diversity } & & & $0.0281 * * *$ & & & & $-0.0944 * * *$ & \\
\hline & & & $(3.21)$ & & & & $(-3.93)$ & \\
\hline \multirow[t]{2}{*}{ Education diversity } & & & & $0.0376^{* *}$ & & & & $-0.585 * * *$ \\
\hline & & & & $(2.15)$ & & & & $(-3.05)$ \\
\hline \multirow[t]{2}{*}{ Size } & -0.00241 & $-0.00324 *$ & -0.00313 & 0.00184 & -0.00782 & -0.0255 & -0.00254 & $-0.0719 * * *$ \\
\hline & $(-1.37)$ & $(-1.74)$ & $(-0.82)$ & $(0.65)$ & $(-0.60)$ & $(-1.62)$ & $(-0.16)$ & $(-2.89)$ \\
\hline \multirow[t]{2}{*}{ Capital } & $-0.0154 *$ & $-0.0206 * *$ & 0.0178 & -0.00678 & $-0.230 * * *$ & $-0.300 * * *$ & $-0.252 * * *$ & -0.284 \\
\hline & $(-1.95)$ & $(-2.36)$ & $(1.03)$ & $(-0.50)$ & $(-3.19)$ & $(-2.66)$ & $(-3.26)$ & $(-1.61)$ \\
\hline \multirow[t]{2}{*}{ Loan } & $0.0211 *$ & $0.0272 * *$ & -0.00782 & 0.00262 & 0.119 & 0.0775 & $0.148^{*}$ & $0.264 * *$ \\
\hline & $(1.92)$ & $(2.36)$ & $(-0.38)$ & $(0.18)$ & $(1.39)$ & $(1.04)$ & $(1.95)$ & $(2.12)$ \\
\hline \multirow[t]{2}{*}{ Foreign bank } & $0.00799 *$ & 0.00482 & -0.000949 & $0.0160 * *$ & -0.0277 & -0.0622 & 0.0424 & $-0.162 *$ \\
\hline & $(1.92)$ & $(1.05)$ & $(-0.10)$ & $(2.09)$ & $(-0.76)$ & $(-1.61)$ & $(1.27)$ & $(-1.73)$ \\
\hline \multirow[t]{2}{*}{ Listed } & -0.0000488 & -0.000913 & $-0.0124^{*}$ & -0.00230 & -0.0308 & $-0.0750 * *$ & 0.00381 & 0.0150 \\
\hline & $(-0.01)$ & $(-0.25)$ & $(-1.68)$ & $(-0.56)$ & $(-1.23)$ & $(-2.26)$ & $(0.13)$ & $(0.48)$ \\
\hline \multirow[t]{2}{*}{ Business group } & $0.0240 * * *$ & $0.0272 * * *$ & -0.00855 & $0.0435 * * *$ & $-0.173^{* *}$ & $-0.253 * * *$ & 0.0268 & $-0.313 * * *$ \\
\hline & $(3.38)$ & $(4.64)$ & $(-0.72)$ & $(5.99)$ & $(-2.30)$ & $(-4.04)$ & $(0.58)$ & $(-3.89)$ \\
\hline \multirow[t]{2}{*}{ Crisis period } & -0.000204 & -0.0000708 & $8-0.000757$ & 0.00282 & $0.0258^{*}$ & $0.0280^{*}$ & 0.0207 & -0.0231 \\
\hline & $(-0.14)$ & $(-0.05)$ & $(-0.16)$ & $(1.28)$ & $(1.79)$ & $(1.88)$ & $(1.05)$ & $(-0.97)$ \\
\hline $\mathrm{N}$ & 352 & 348 & 348 & 349 & 389 & 355 & 348 & 350 \\
\hline F-stat & $4.18 * * *$ & $6.25 * * *$ & $3.50 * * *$ & $10.12 * * *$ & $2.40 * *$ & $2.81 * * *$ & $3.17 * * *$ & $2.49 * *$ \\
\hline Endog. Test (Chi-sq) & $12.92 * * *$ & $13.77 * * *$ & $6.95 * * *$ & $7.33 * * *$ & $2.72 * * *$ & $9.44 * * *$ & $7.00 * * *$ & $9.13 * * *$ \\
\hline
\end{tabular}

Note: The table above reports IV/2SLS regression using net interest margin (NIM) and the ratio of operating expense-tooperating income (OEOI) as the dependent variables. Superscripts $*{ }^{* *}, * * *$ represent the significance at $\mathrm{p}<0.1, \mathrm{p}<0.05$, and $p<0.01$ respectively. t-statistics shown in parentheses are corrected for White heteroskedasticity. NIM is defined as net interest income divided by average of earning assets. OEOI is the ratio of operating expenses divided by operating incomes. Female is the percentage of female on the board. Ehtnog diversity is the average diversity index of ethnicity and nationality. Professional diversity is the average index of banking experience and tenure diversity. Education diversity is the average diversity index of education level and education type. Size is the logarithm of the bank's total assets. Capital is the ratio of bank's equity to its assets. Loan is the ratio of total loans to total assets. Foreign bank is a dummy equals one if the bank is owned by foreign shareholders, zero otherwise. Listed equals one if the bank is publicly listed, zero otherwise. Crisis denotes one for year 2008 and zero otherwise. 


\section{Appendix A Definition of variables}

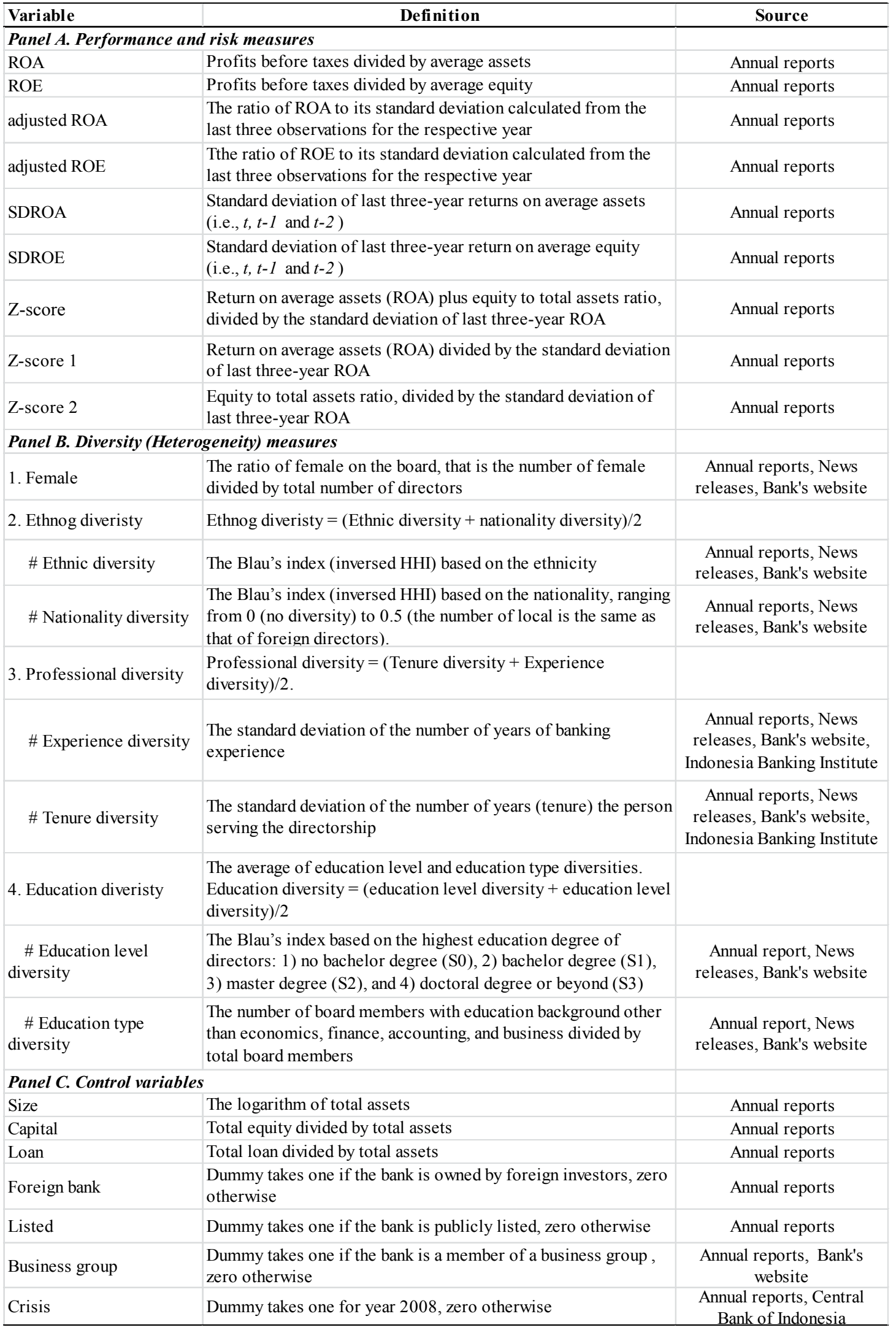

